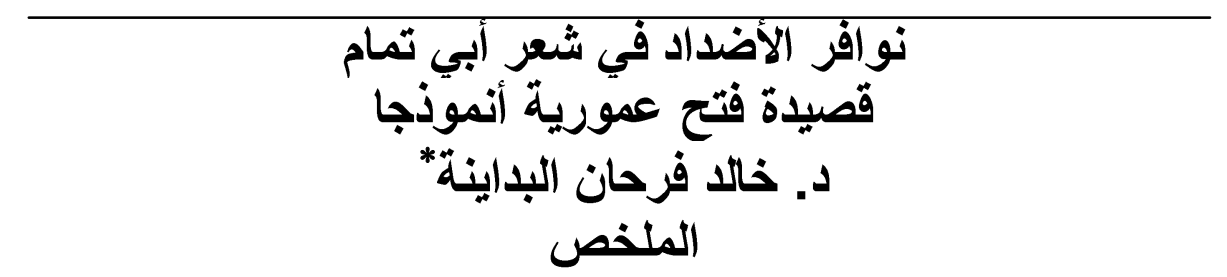

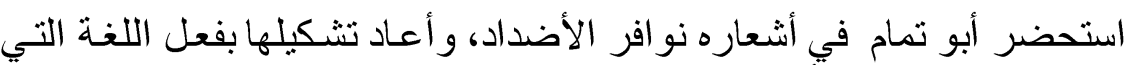

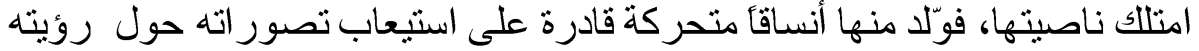

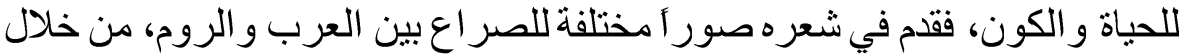

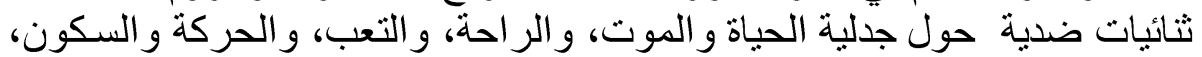

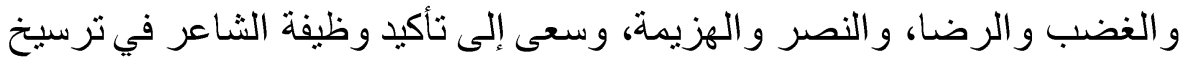

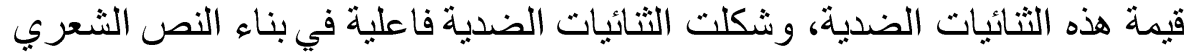

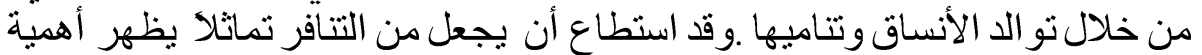

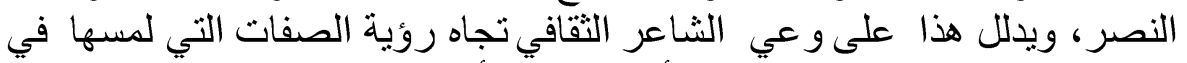

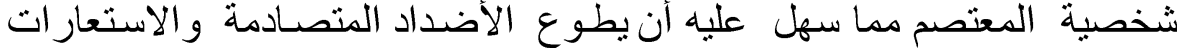

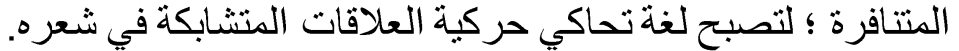

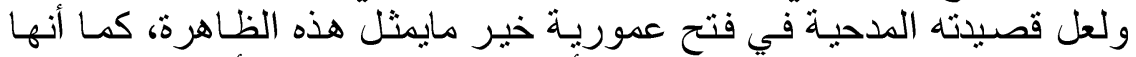

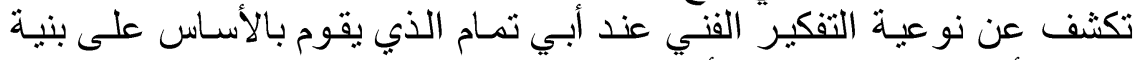

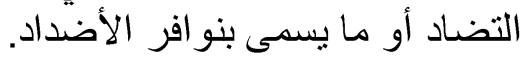

×أستاذ مساعد / جامعة الطفيلة التقنية / كلية الآداب / قسم اللغة العربية . 
نوافر الأضداد فى شعر أبى تمام قصيدة فتح عمورية أنموذجا

\title{
Khaled Farhan
}

\begin{abstract}
In his poems Abu Tammam evokes the paradoxical terms, and re-formed by the language that he had grasped, which gave rebirth and made him able to accommodate the perceptions about his vision of life and the universe. $\mathrm{He}$ introduced different images of the conflict between the Arabs and the Romans, through the binary oppositions on the dispute of life and death, and comfort, tiredness, movement and stillness, anger and satisfaction, victory and defeat. He sought to confirm the function of the poet in establishing the value of these binaries and these binaries formed a very effective attitude in building the poetic text through breeding patterns. In addition, he was able to make out of the disharmony homogeneous, which shows the importance of victory. This demonstrates the cultural awareness of the poet towards the vision of the qualities that he touched in Al Mu'tasim personal qualities, which made easy for him to adjust its opposites, collide, and disparate metaphors into the language simulated dynamic interrelationships in his hair. Perhaps the poem in the open Amuriyah is a good example for this phenomenon as it reveals about the quality of the artistic thinking of Abu Tammam, who is essentially build up his structure on the so-called contrast or binary oppositions.
\end{abstract}

تحاول هذه الدر اسة فهم ظاهرة نو افر الأضداد في شعر أبي تمام، وفلك أسرار 


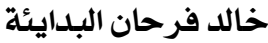

هذه الظاهرة العقلية الغريبة المعقدة التي تقوم أساسا على المتضادات المتتافرة من

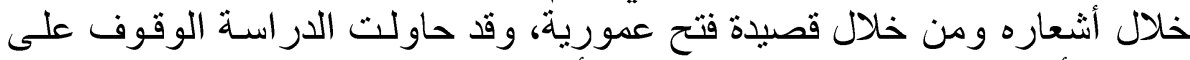
بعض الأمثلة التي تمثل هذه الظاهرة من أجل الوصول فئل إلى استجلائها في قصيدة

$$
\text { فتح عمورية. }
$$

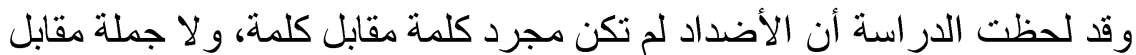

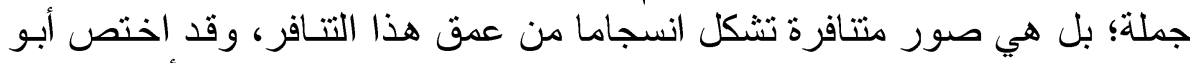

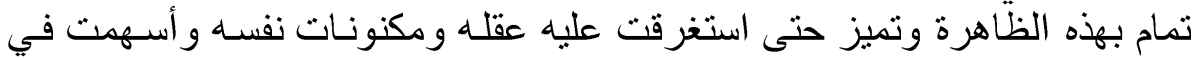

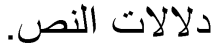

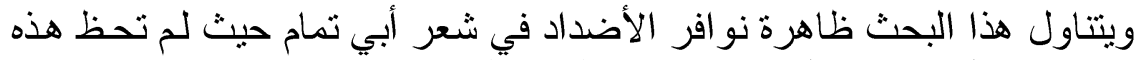

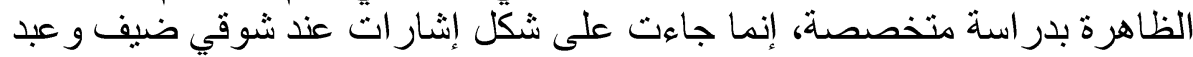
الكريم يافي.

ومن أجل الوقوف على هذه الظاهرة بوصفها سمة أسلوبية لافتة في شعر أبسي تمام كان لا بد من تعريف المصطلح، كظاهرة فكرية عقلية تجسدت في أشعار أبي الهي

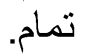
وقد تر اعى للباحث أن تكون الدر اسة في محورين: تتاول الأول ظاهرة الثنائيات

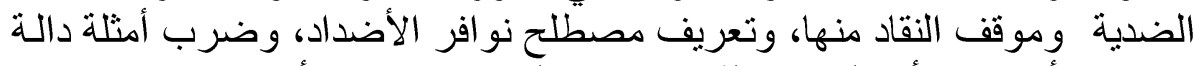

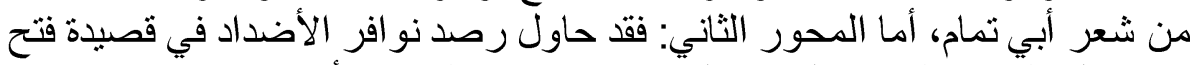

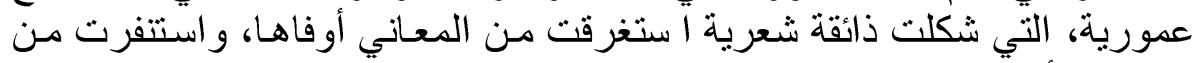

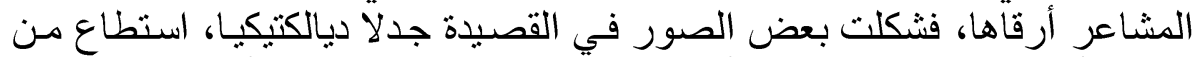

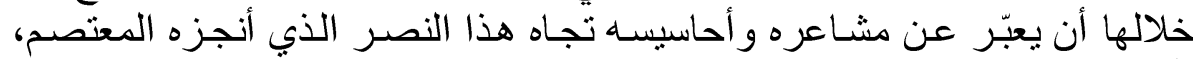

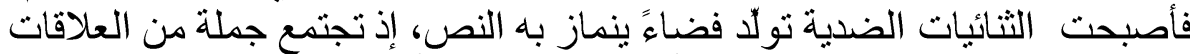

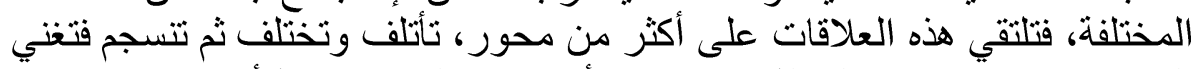

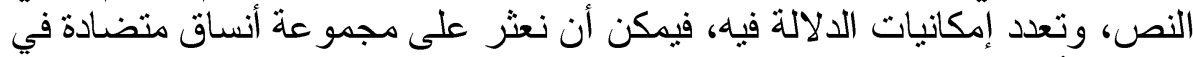

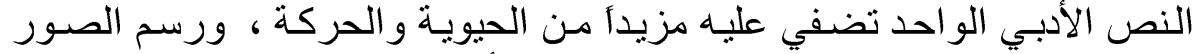

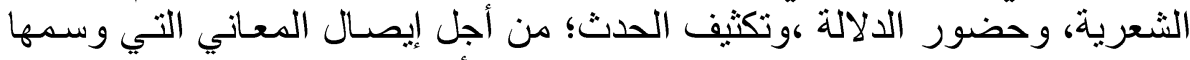

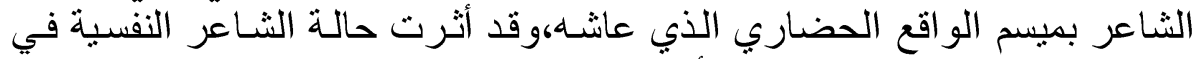

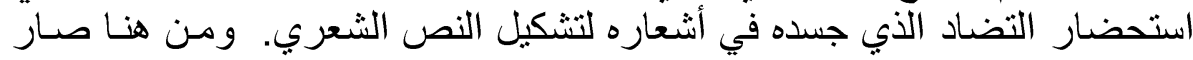

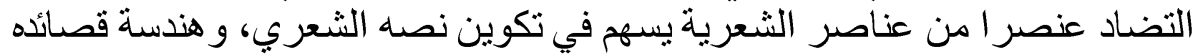
فلا نكاد نقع على قصيدة تخلو من نو افر الأضداد.

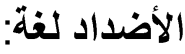

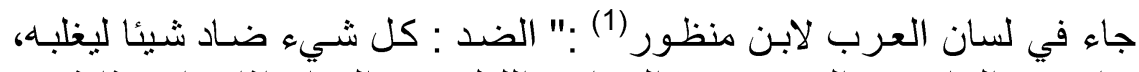
و السواد ضد البياض، والموت ضد الحياة، و الليل ضد النهار إذا جـاء هذا ذهب 
نوافر الأضداد فى شعر أبى تمام قصيدة فتح عمورية أنموذجا

ذللك)، ضد الثيء وضديده : خلافه، وقد يكون الضد جمعاه، و والقوم على ضد وند واحد

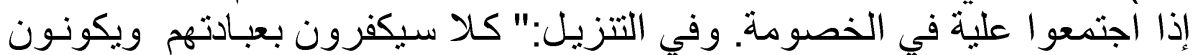

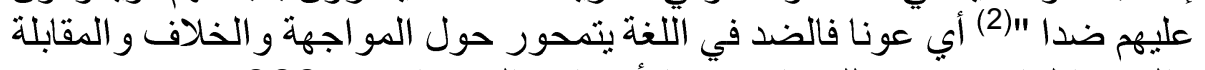

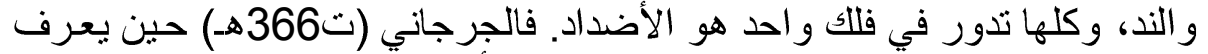

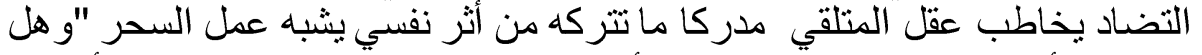

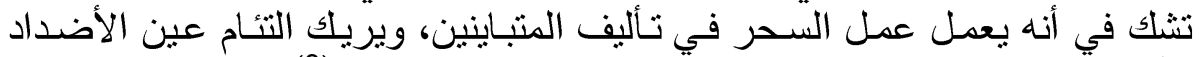

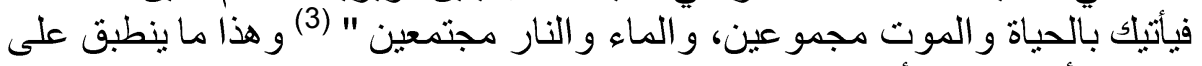

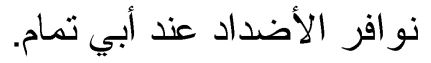

ويؤكد ذلك العسكري (ت395هـ)بقو له:"'إن الناس قد أجمعو العلى أنه الجمع بين

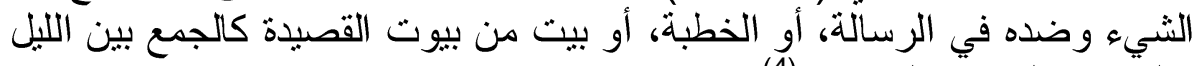
و النهار ، والسو ادو والبياض "(4).

وخلاصة القول: إن نر اثنا النقدي القديم حافل بمثل هذه الدصطلحات الندات البلاغية

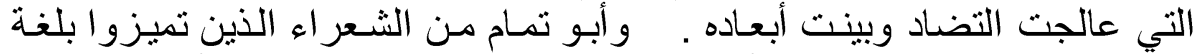

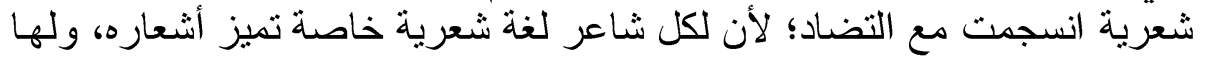

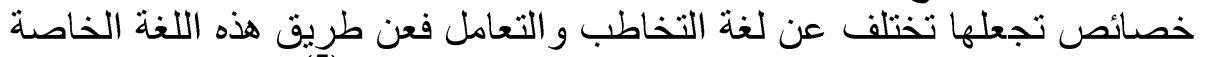

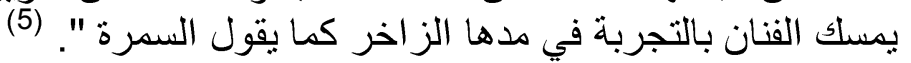

\section{طبيعة التضاد عند القدماء والمحدثين:}

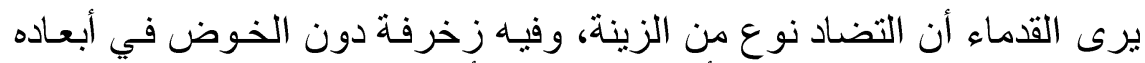

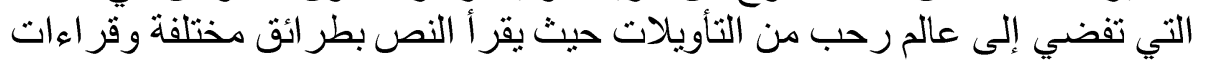

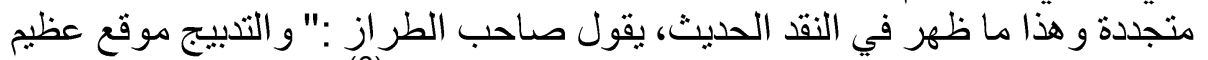

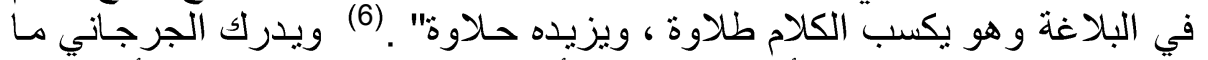

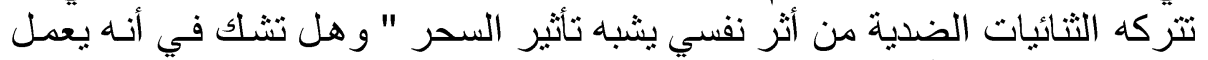

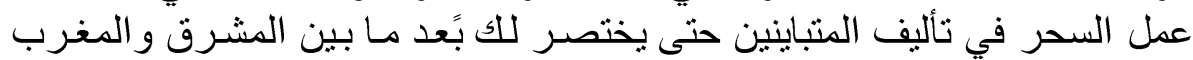

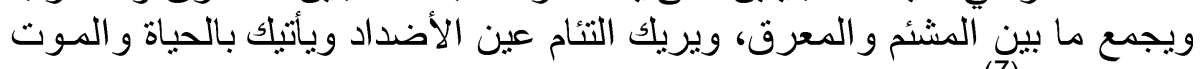
مجموعين ماتبين

وليس التفكير الجدلي غريبا عن الشعر العربي، كما أن التراث العربي الإسلامي

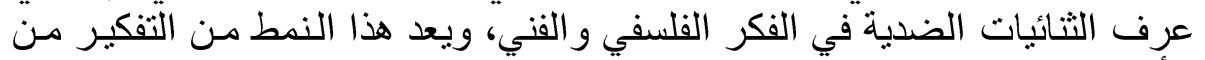

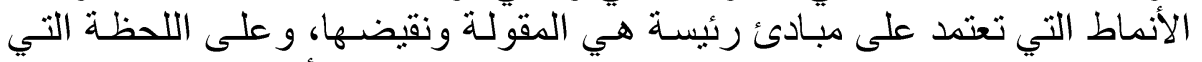

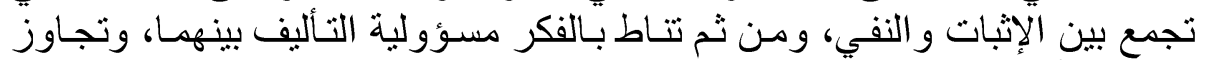

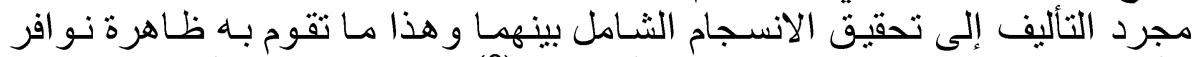

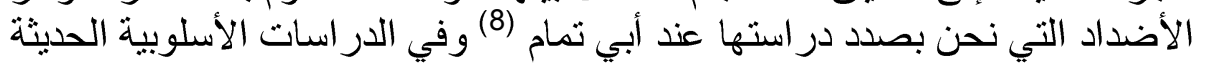

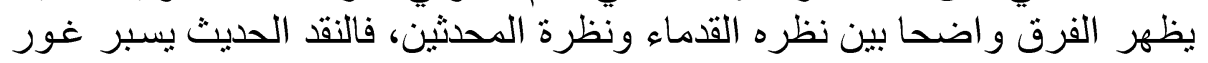


خالد فرحان البدايئة

النص وما فيه من تضاد فهناك عمليات مكثفة تتم داخل بنية التضاد في العمق بحيث

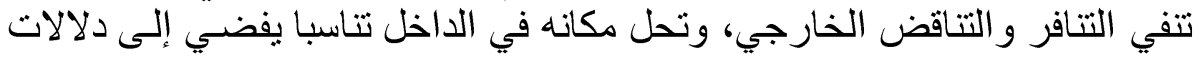

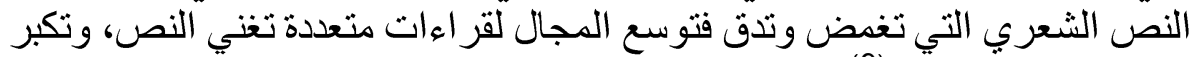

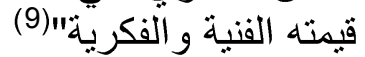

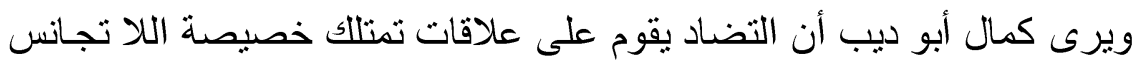

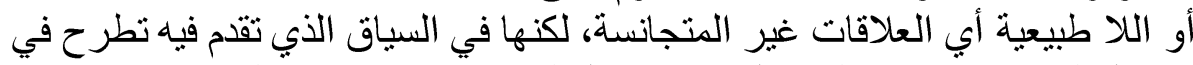

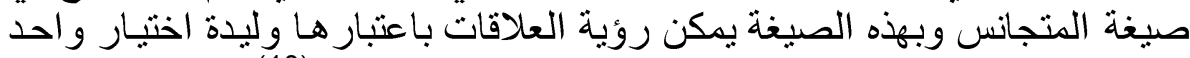

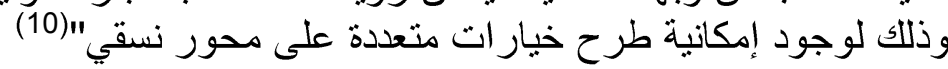

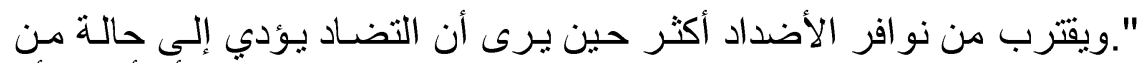

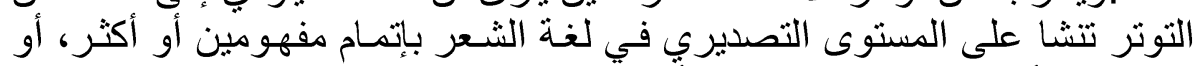
تصويرين أو موقفين لا متجانسين أو متضادين في بنية والئ واحدة يمثل فيها كل منهما

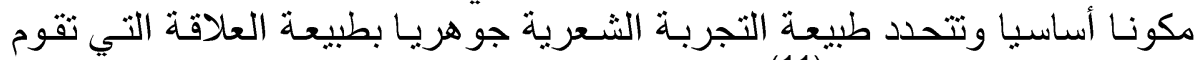
بينهما ضمن ضاسن" هذه البنية " "(11)

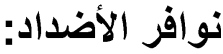

أسلوب غريب معقد يمتاز به الشعر اء أصحاب الفن الرفيع واء وهي حالة لا يقدر

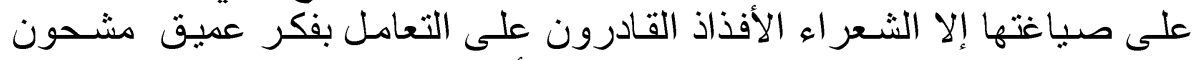

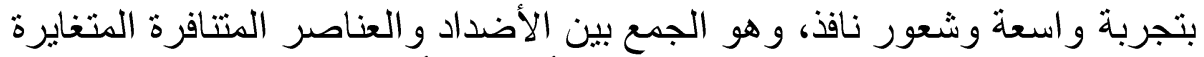

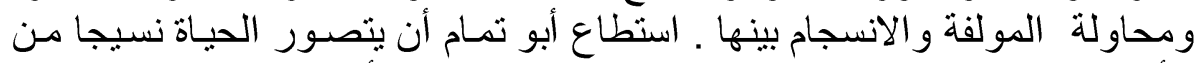

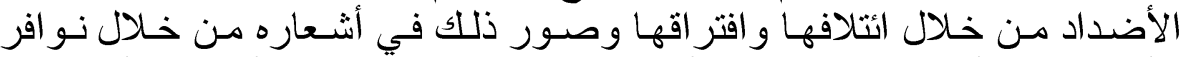

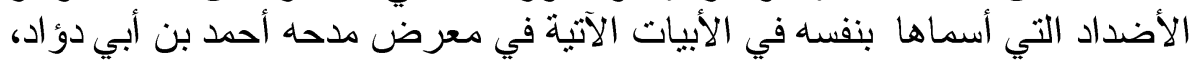

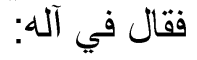

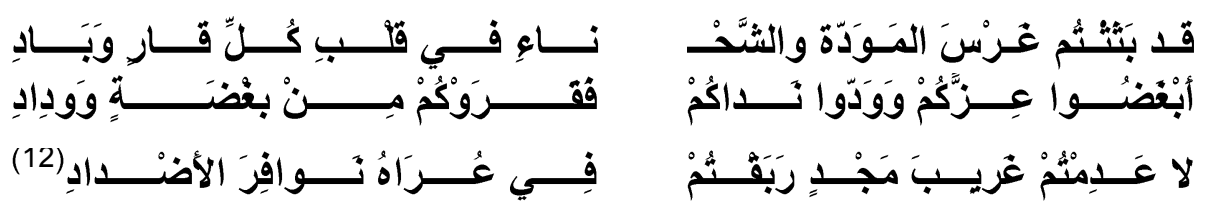

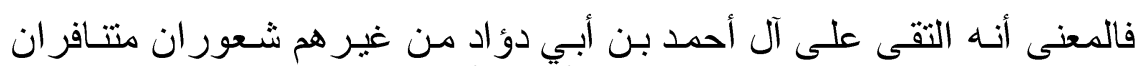

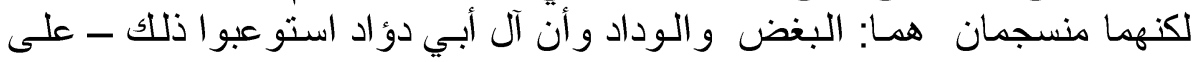

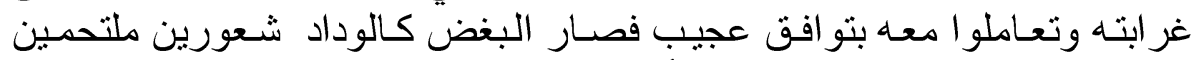

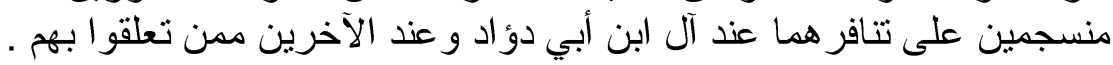

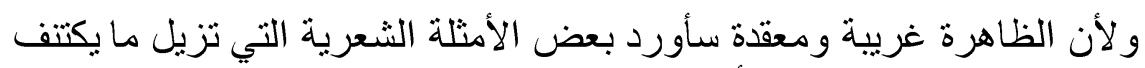

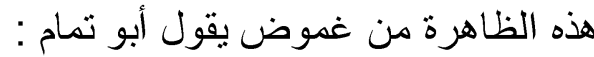


لقد وعى الثاعر مهمته الأساسية أثناء نظم الأبيات و غيرهـا في فصـائده فبناهـا

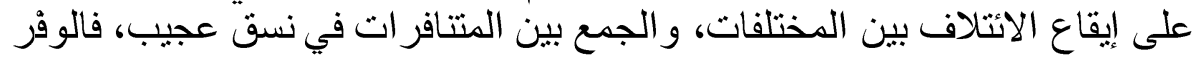

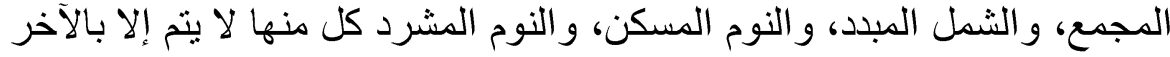

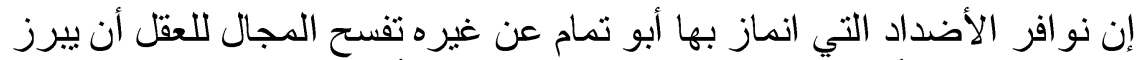

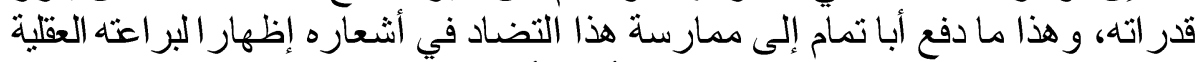

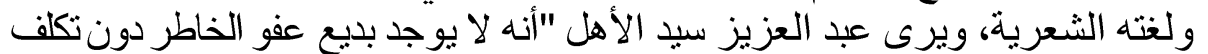

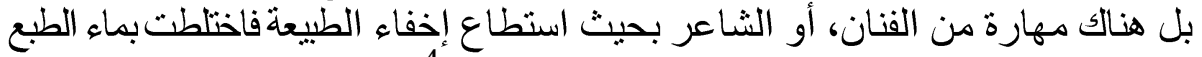

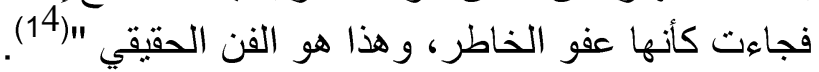

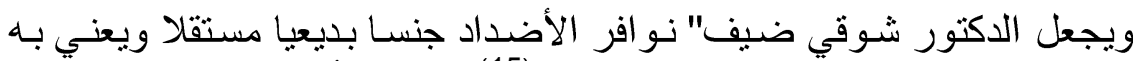

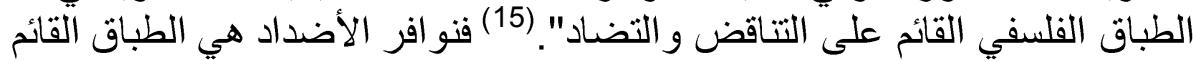

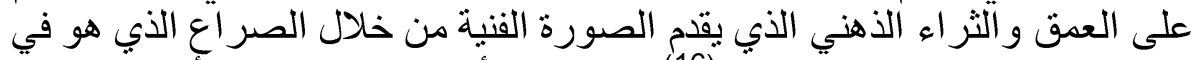

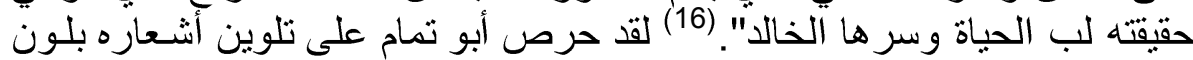

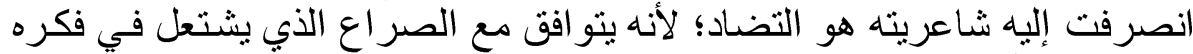

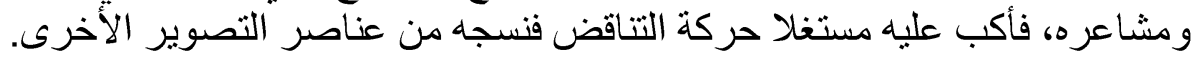

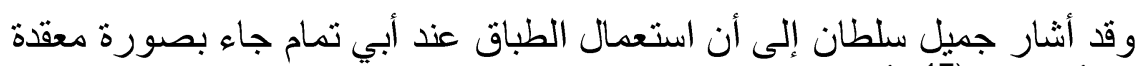

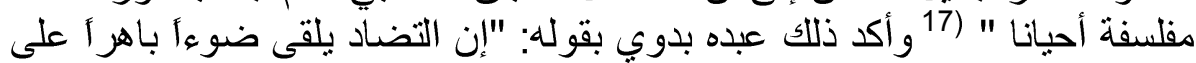

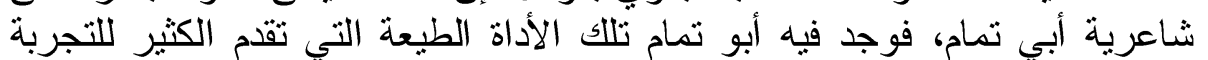

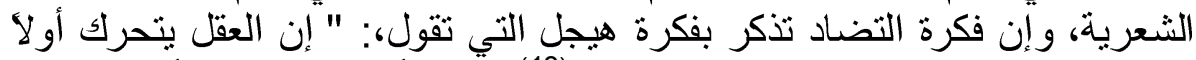

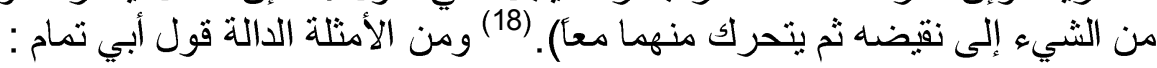

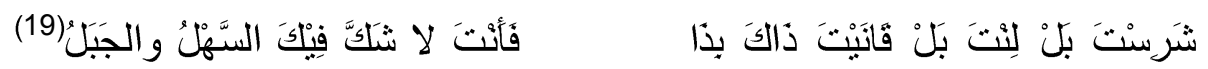
فالمعنى أنه وصفه بوصفين متتافرين لكنها منسجمان : هما سهولة التعامل

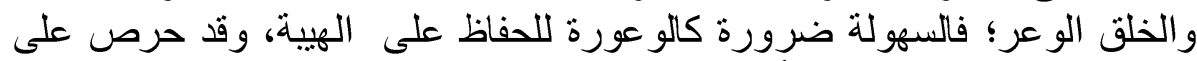

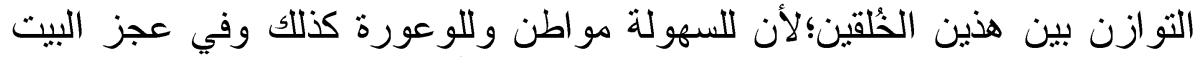

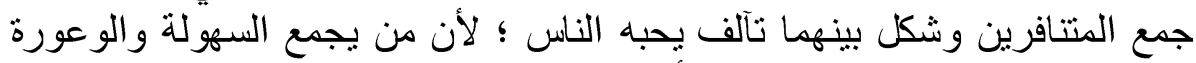

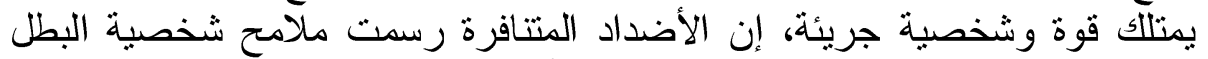

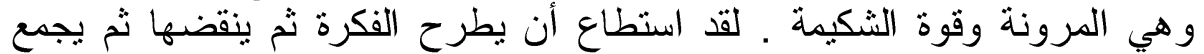

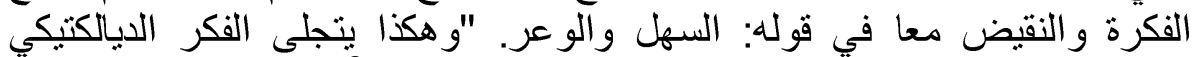

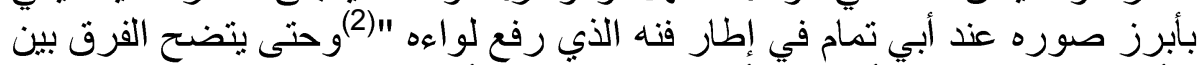

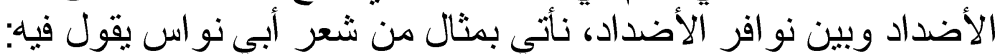


خالد فرحان البدايئة

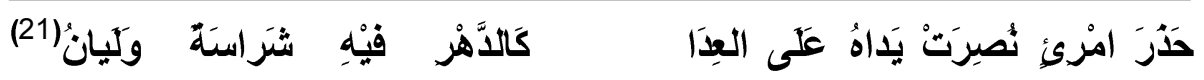

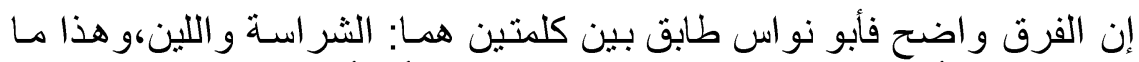

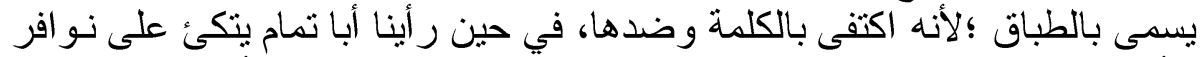

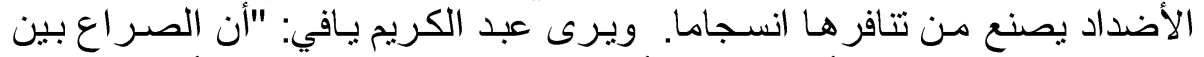

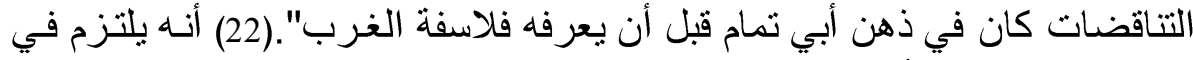

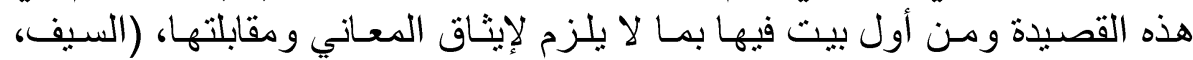

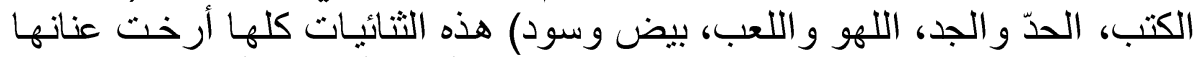

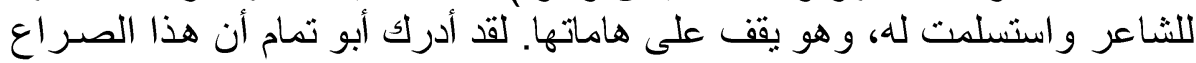

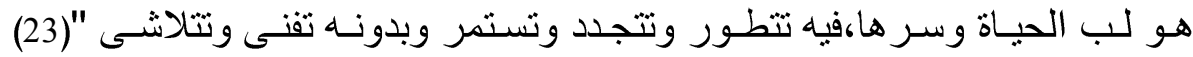

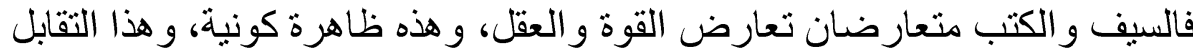

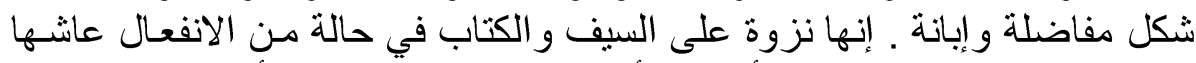

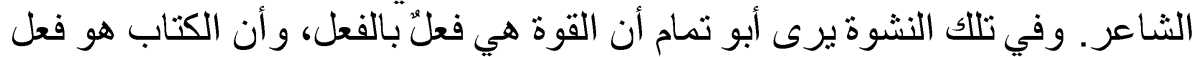

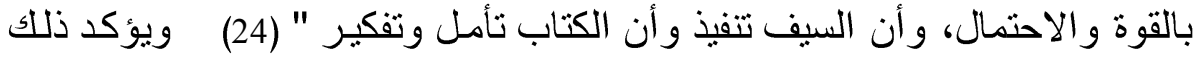

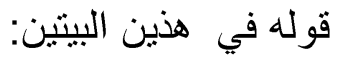

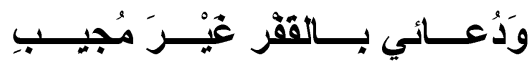

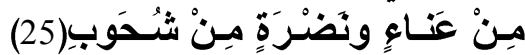

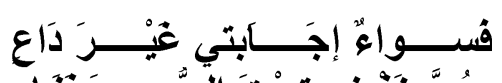

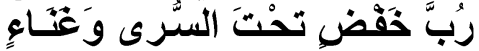

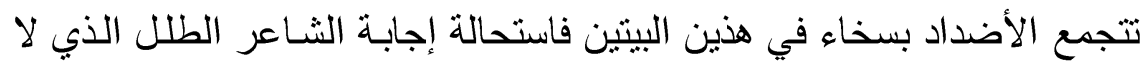

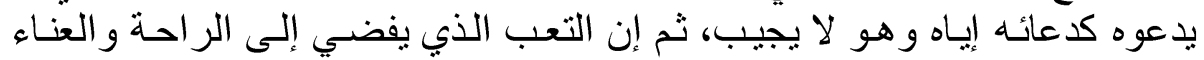

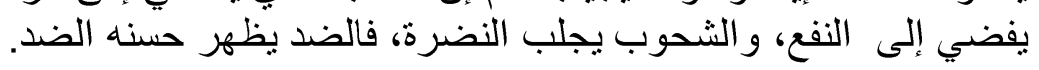

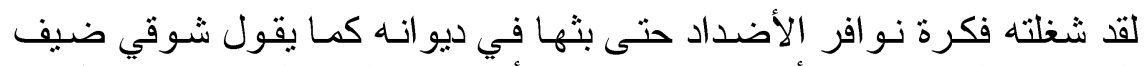

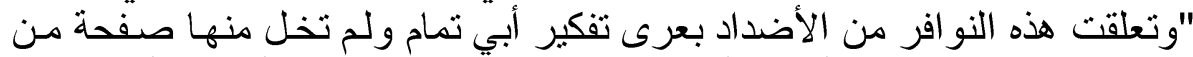

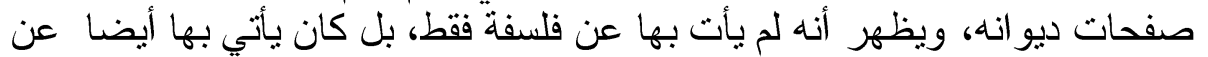

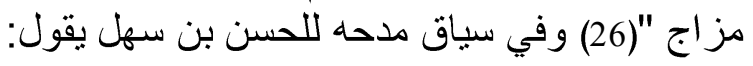

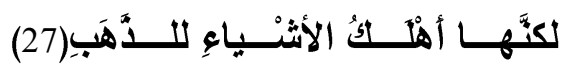

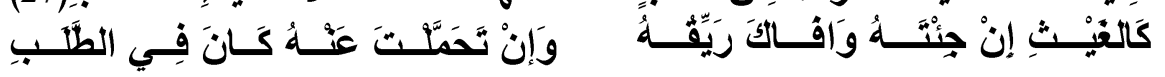

في البيت السابق جاءت الصفة المادية لتندل على الصفة الأخلاقية (شيمة غر آلاء

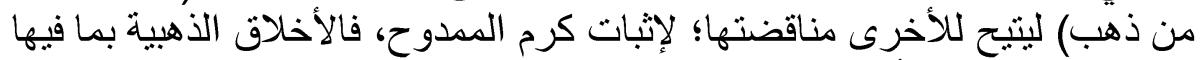

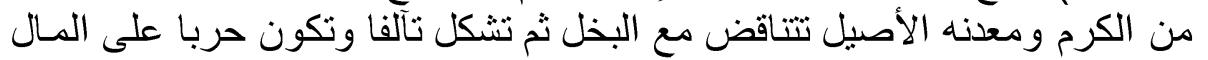

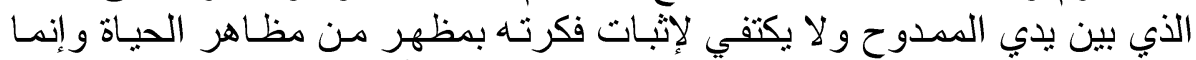

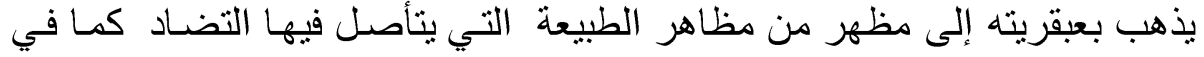


نوافر الأضداد فى شعر أبى تمام قصيدة فتح عمورية أنموذجا

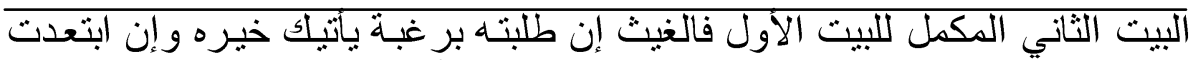

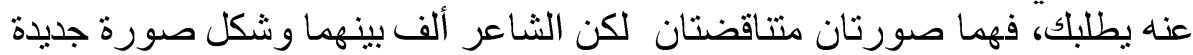

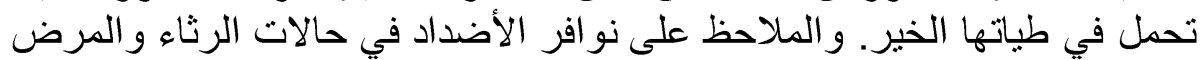
تكون أكثر صفاء وتأملا ومن الأمثلة على ذلك تأمله في مرض ألى أحمد بن أبي دؤ اد الدا

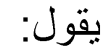

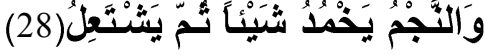

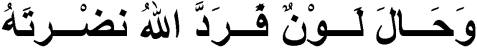

يطمئن أبو تمام ممدوحه بأن اللون و إن تغير فسوف يعود إلي طبيعته ثم يأتي له له

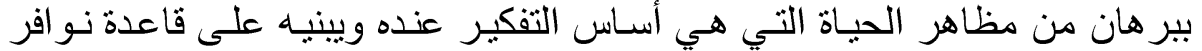

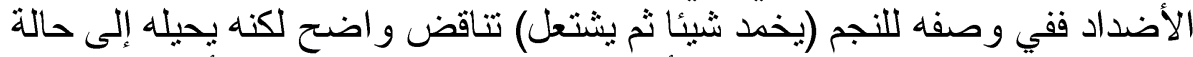

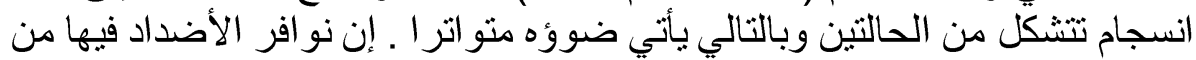

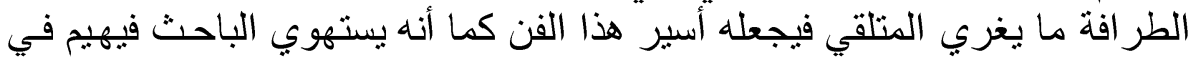
ديوان أبي تمام متصيدا للأمثلة التي تقوم على المتضادات المتنافرة يقول:

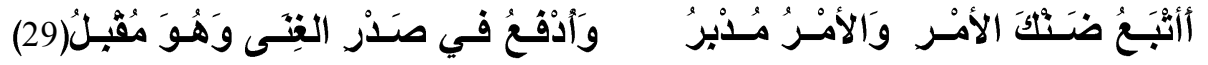

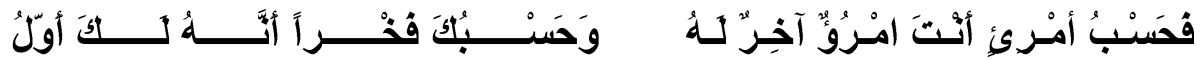
في البيت متضادات عدة تتتافر وتتقاطع هي (مدبر، و وقبل، و أخر ، و أول) حقا

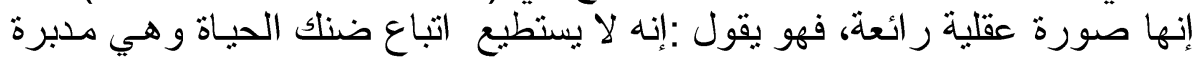

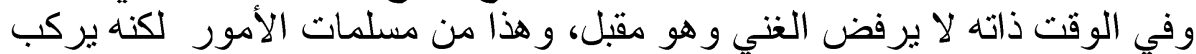

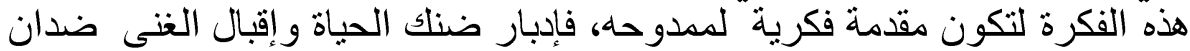

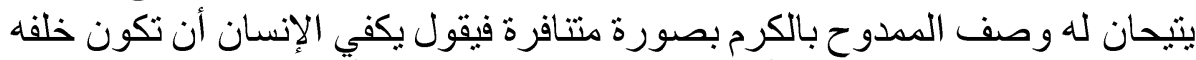

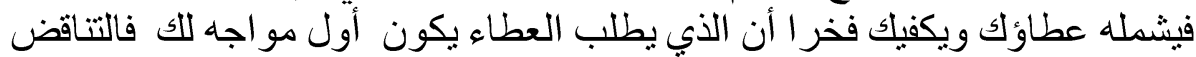
و التنافر في الصورة بشكل انسجاما في صورة جديدة هي كرم المددوح وحظ النيأئلئل

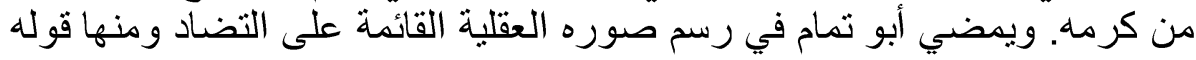
في هذا البيت:

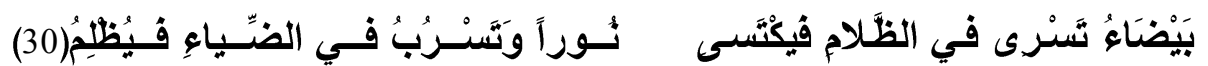

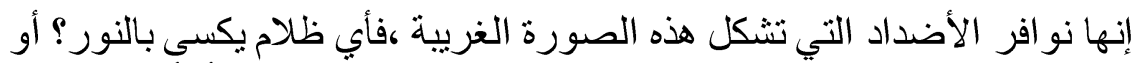

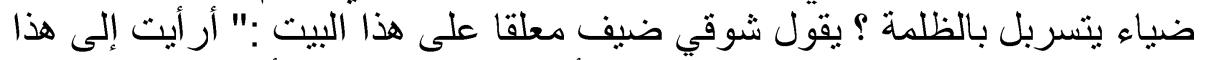
التضاد و هذا الضياء المظلم ؟ إن حقائق الأشياء تتغير في شعر أبي تمـام على هذه الته

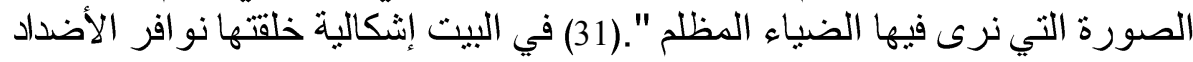


خالد فرحان البدايئة

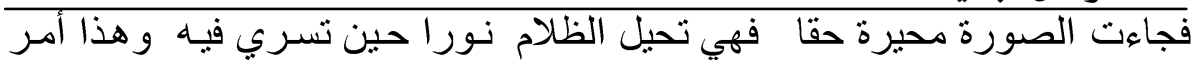

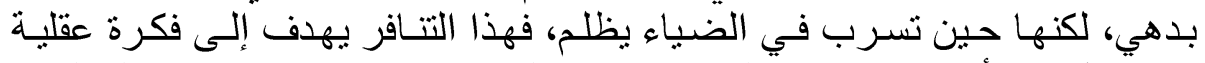

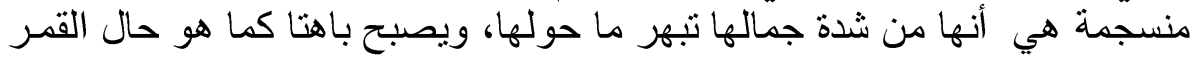

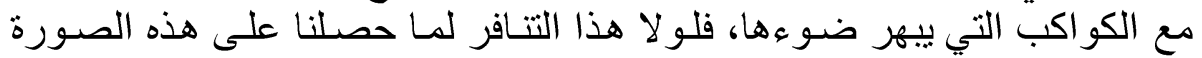

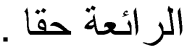

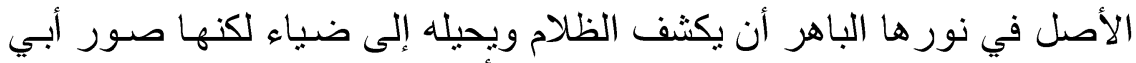

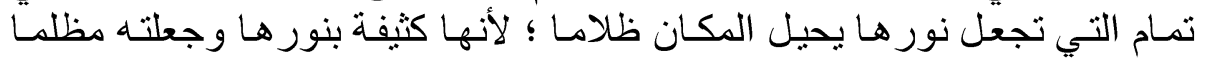

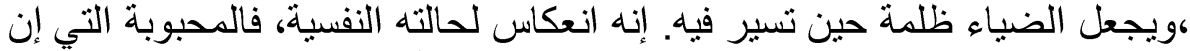

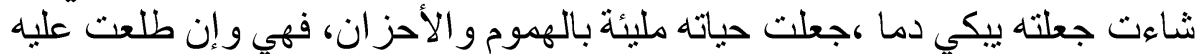

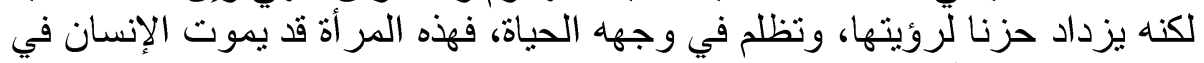

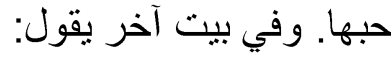

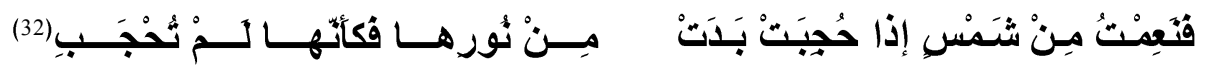

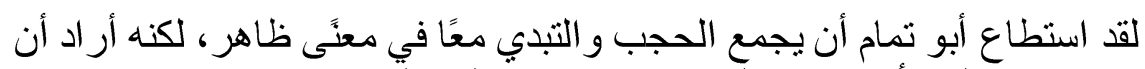
يصور شدة جمالها بأنه يخرق الحجب فيبدو من خلف الحجاب .

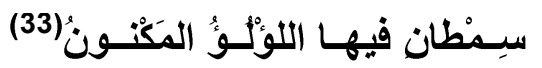

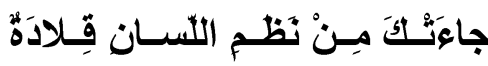

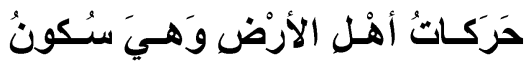

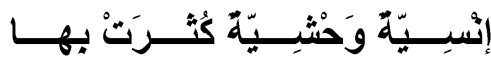

حين تشرق القصيدة بالرؤيا المبنية على نو افر الأضداد، تغدو مر آة تعكس تضاد النياد

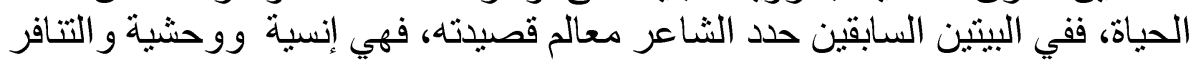

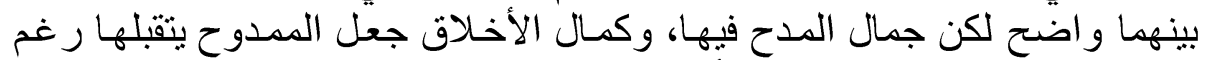

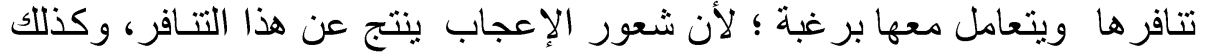

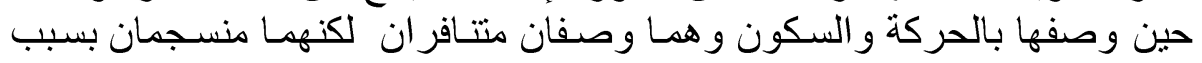
إعجاب المتلقين لها بها به

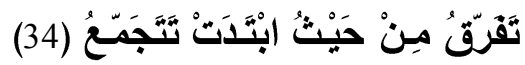

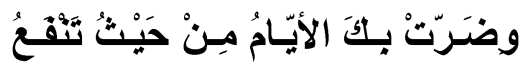

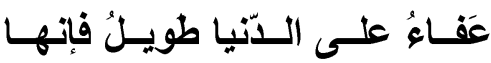
وَضَلْ بكَ المُرْتادُ مِنْ حَيْثُ يَهْنَّدِي

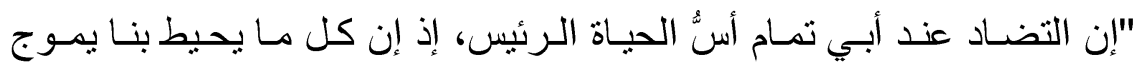
بالتتاقض، وقد قاده هذا الفهم إلى تواتر الصـور المتتافرة " (34)، فيقول في البيتين 
نوافر الأضداد فى شعر أبى تمام قصيدة فتح عمورية أنموذجا

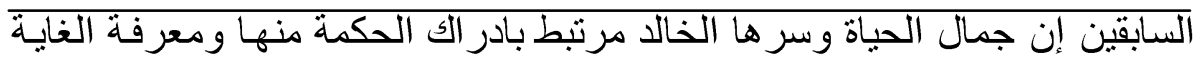

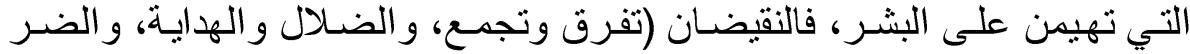

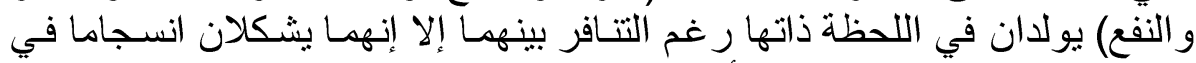

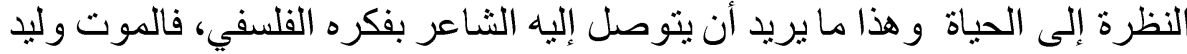

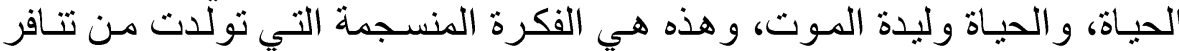
الاضضداد في البيتين السابقين.

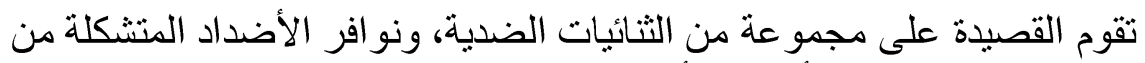

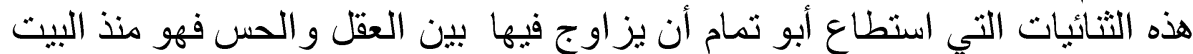

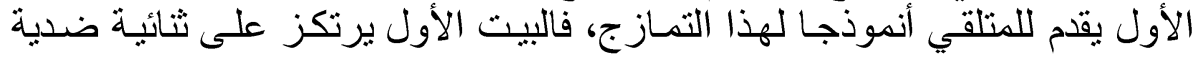

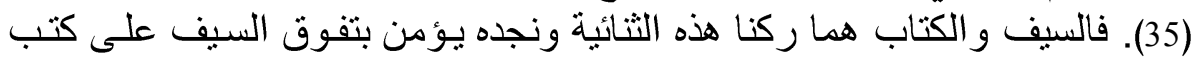

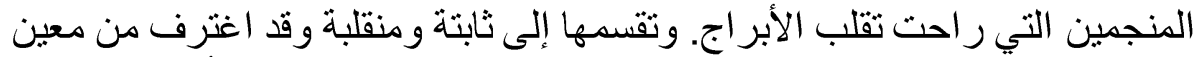

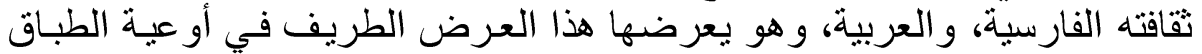

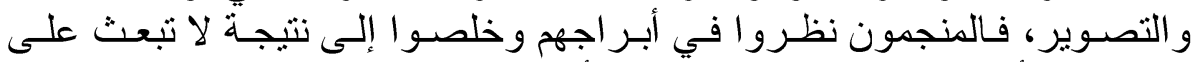

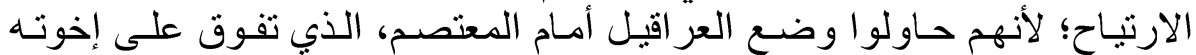

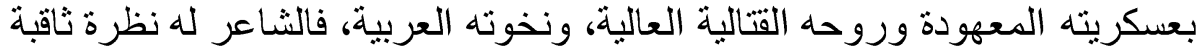

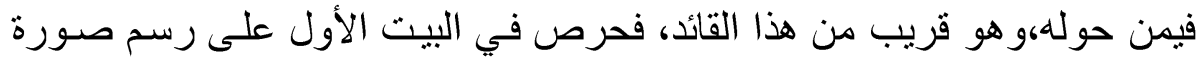

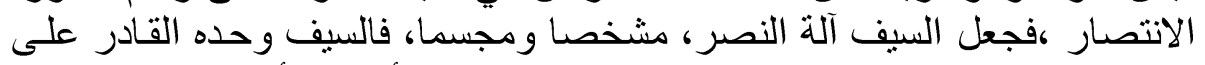

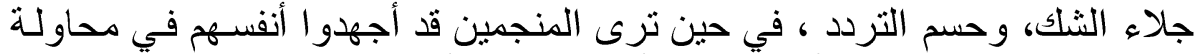

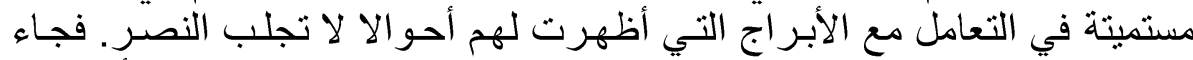

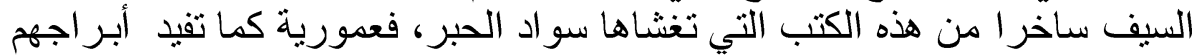

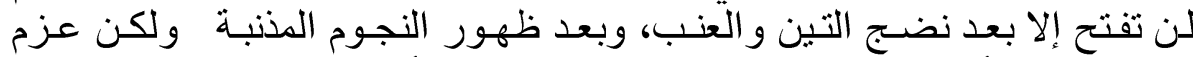

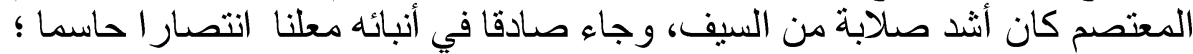

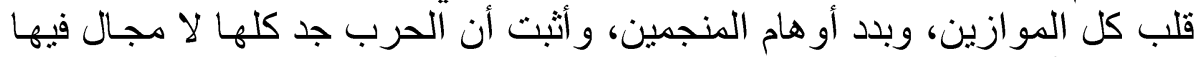

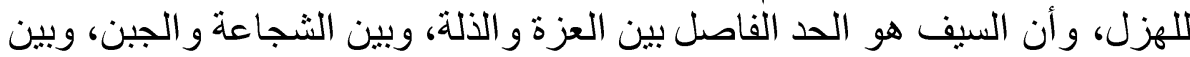

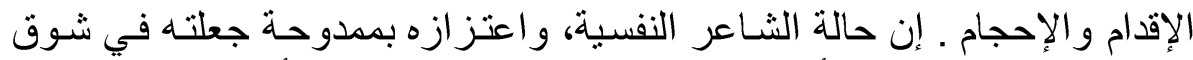

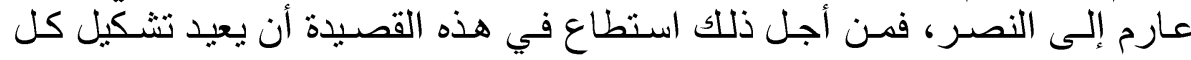

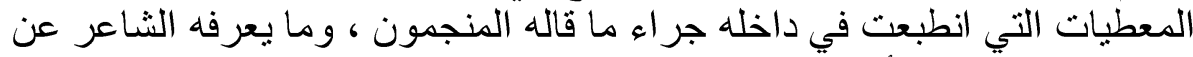

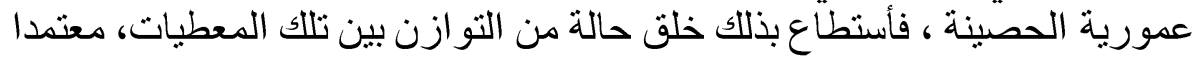

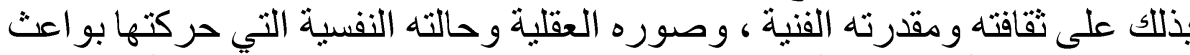

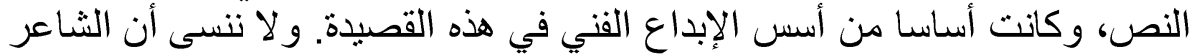

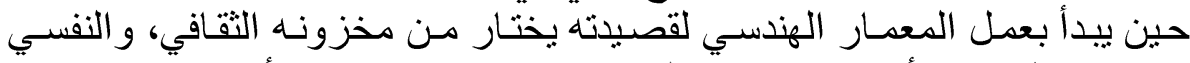
ويضفي عليها من أحاسيسه، و عو اطفها، ورؤاه ،و هذا ما قام بـه أبو تمأم في بائيته المشهورة .

إن هذه القصيدة التي سنبحث عن نو افر الأضداد في ثنايـا أبياتها ليست مجرد 
خالد فرحان البدايئة

أصوات وتر اكيب تطرب المتلقي بإيقاعها الذي اختاره الثـاعر على أنغام البحر

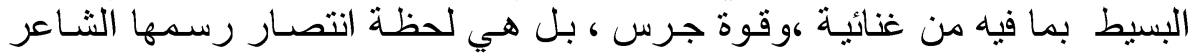

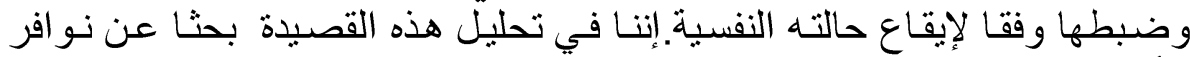

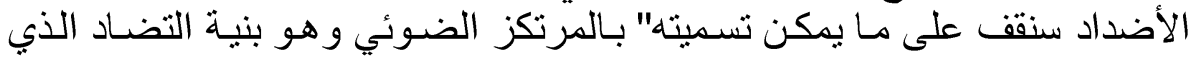

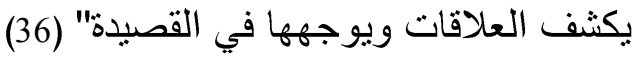

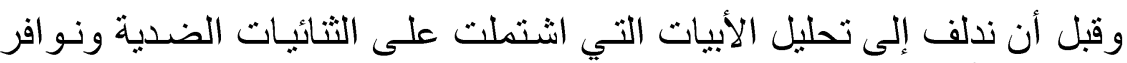

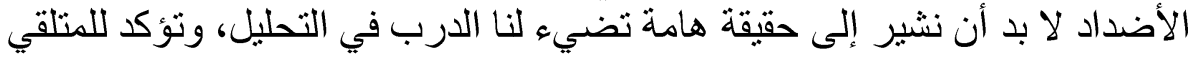

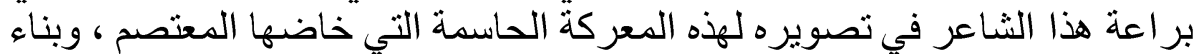

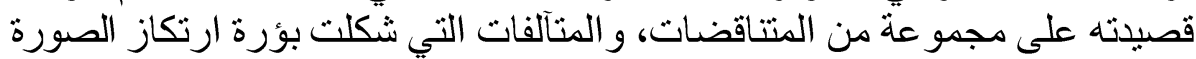

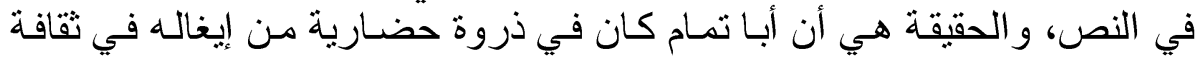

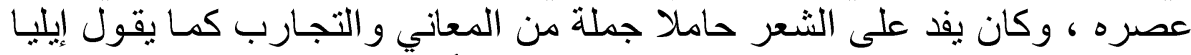

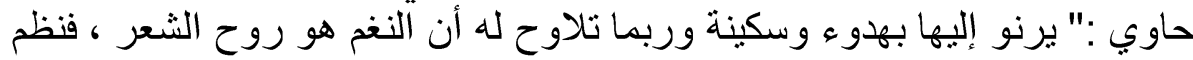

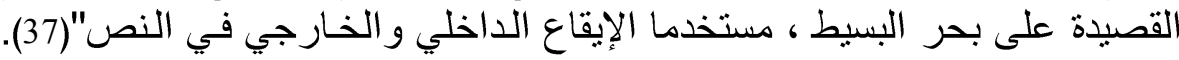

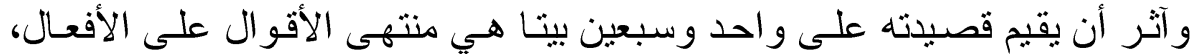

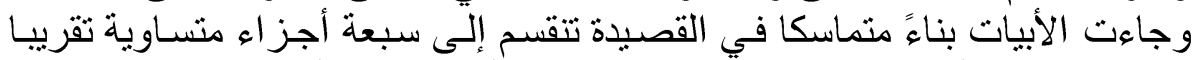

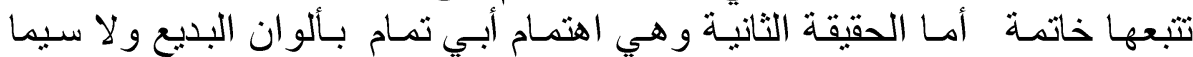

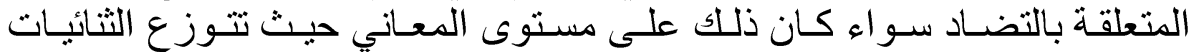

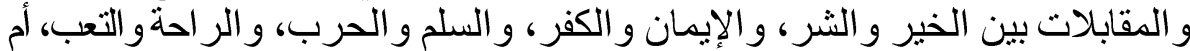

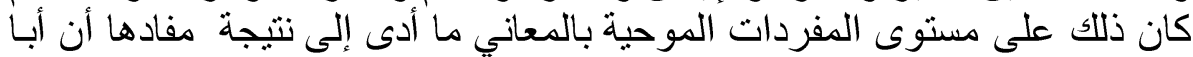

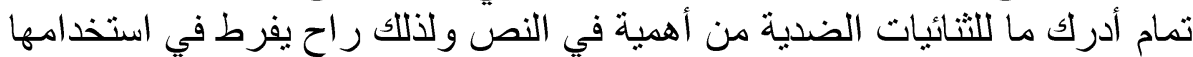

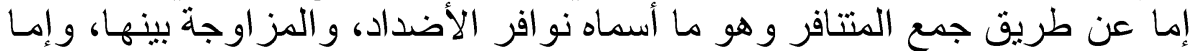

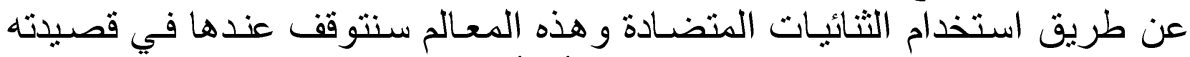

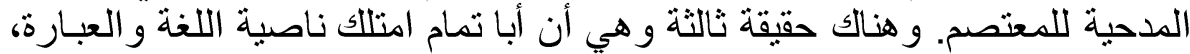

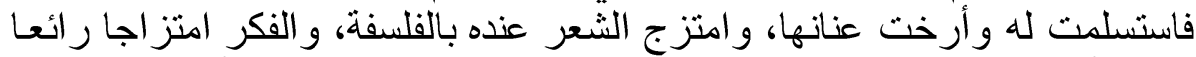

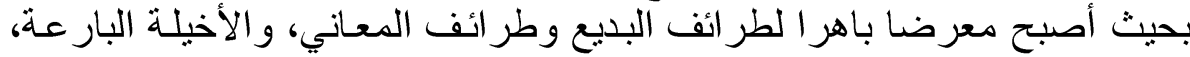

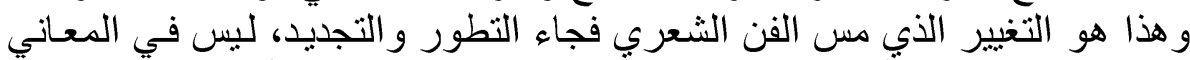

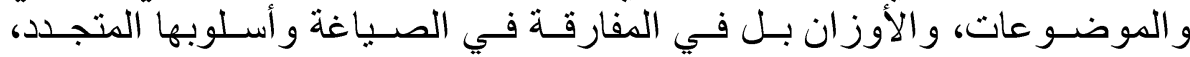

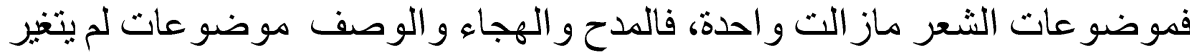

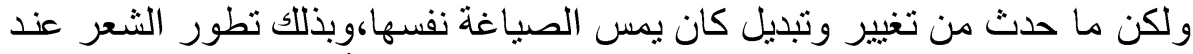

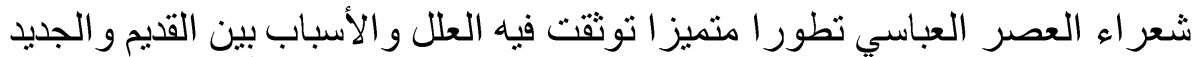

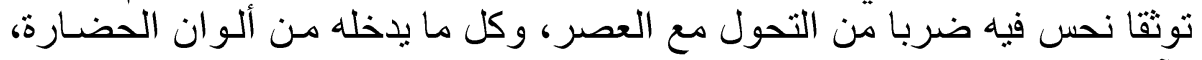

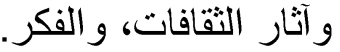

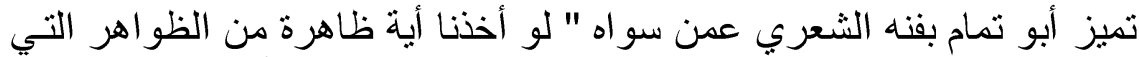

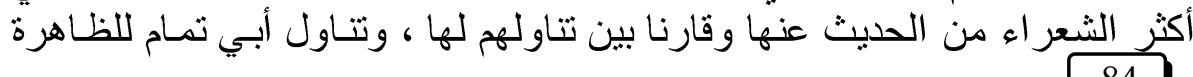


نوافر الأضداد فى شعر أبى تمام قصيدة فتح عمورية أنموذجا

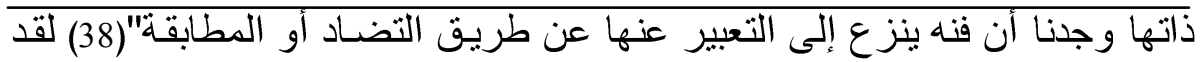

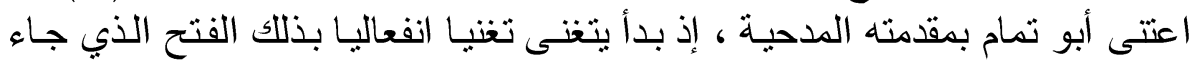

نتيجة حتمية لفلسفة القوة التي آمن بها الثناعر" . (39)

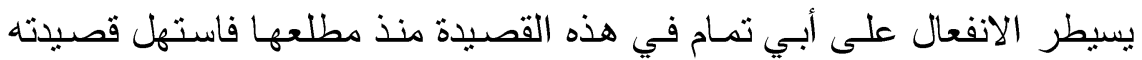
بمقدمة تتناسب مع الانغعال

جلال الموقف وما يؤكده الو اقع من تكذيب المنجمين.

في حَدِّه الحَدُّ بَيْنَ الجِدِّو الَّلَبِب(40)

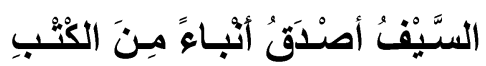

لقد شكل مطلع القصيدة مفتتح الثر وهو السيف، رمز القوة فقد استجمع أبو تمام

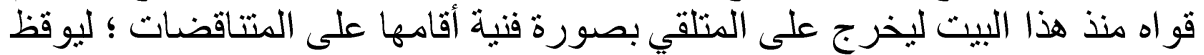

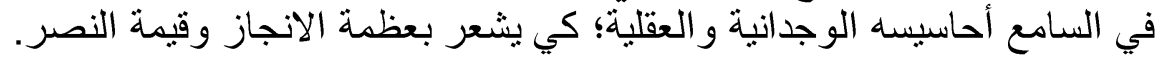

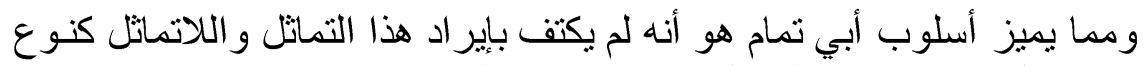

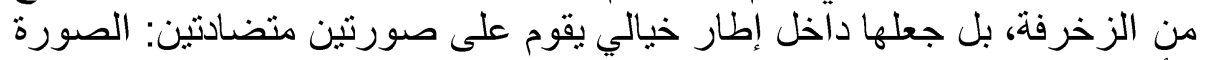

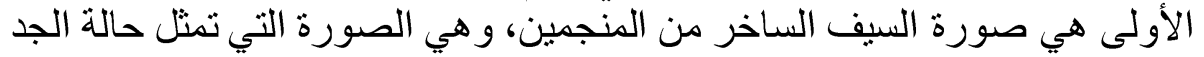

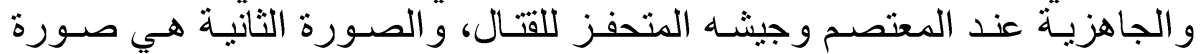

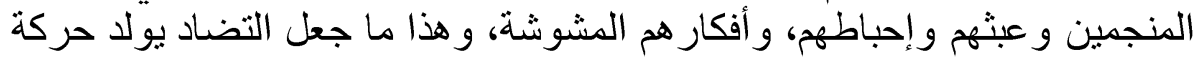

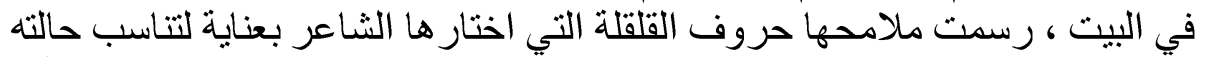

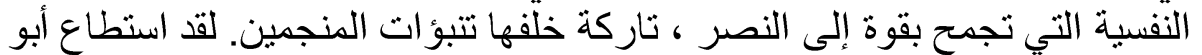

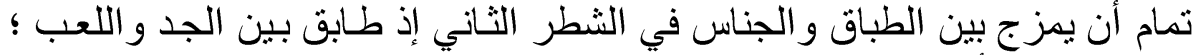

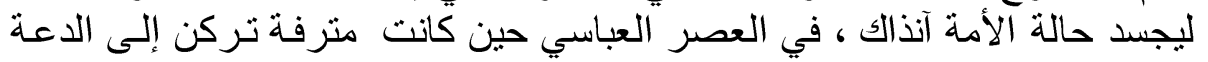

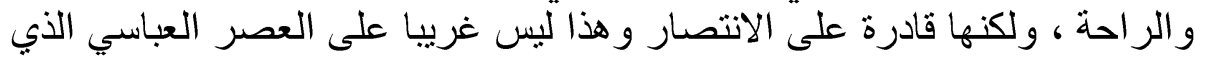

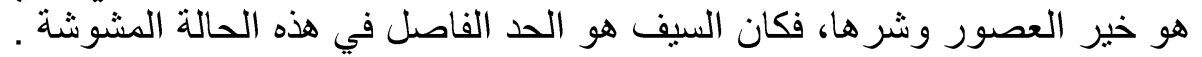

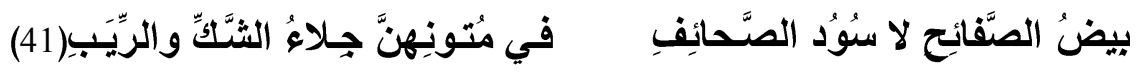

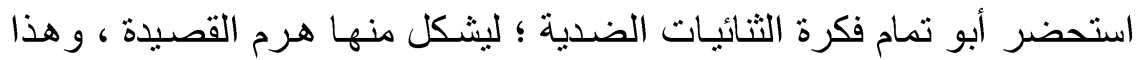

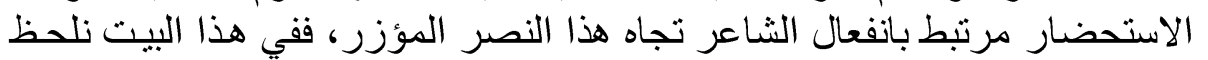

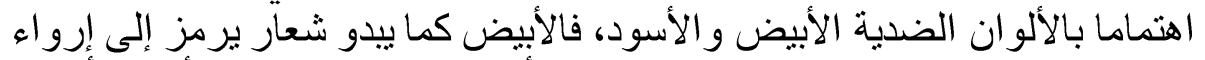

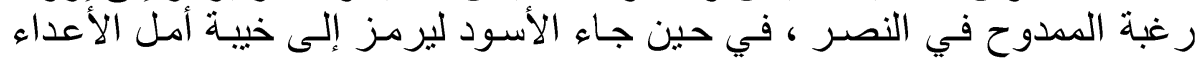
و المنجمين ، وما حل بهم، فالتضـاد في البيت يشعرنا بإحساس بدهي هو شيز شعور عارم 


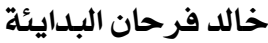

بأن الثاعر يمتلك ناصية العبارة يتصرف بها كما يشاء ويطيب لله و أنـه نـال منها

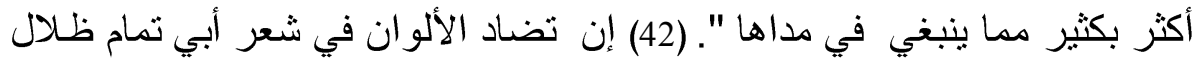

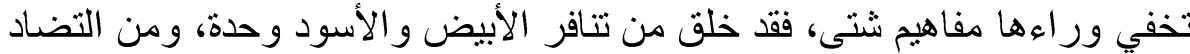

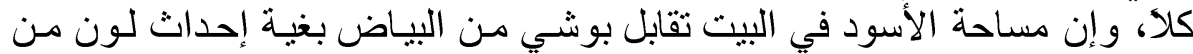

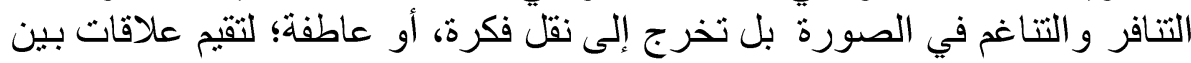

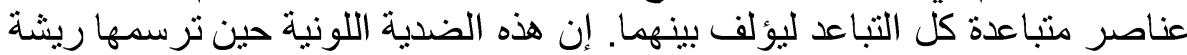

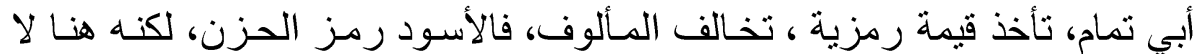

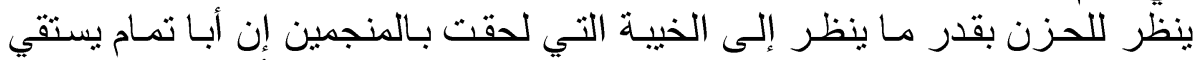

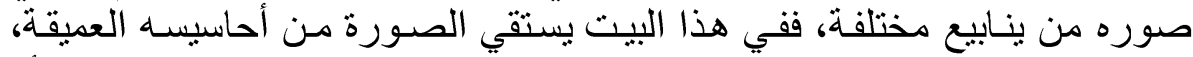

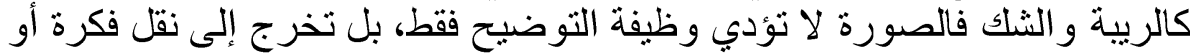

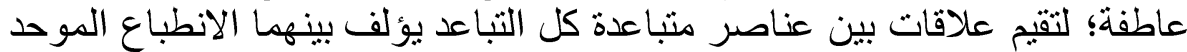

و هذا ما يمكن أن نطلق عليه الإيحاء ".(43)

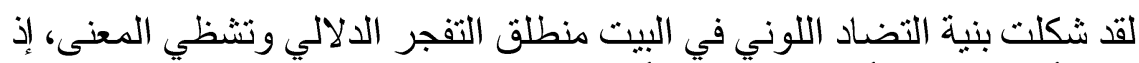

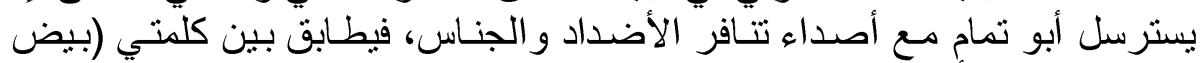

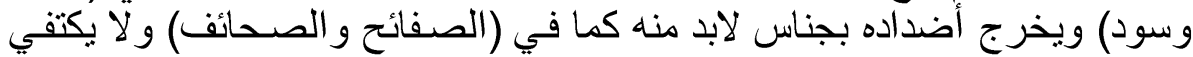

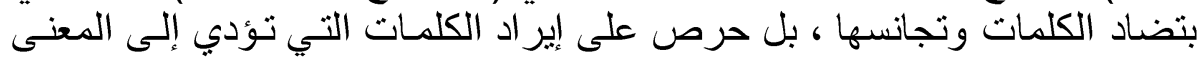

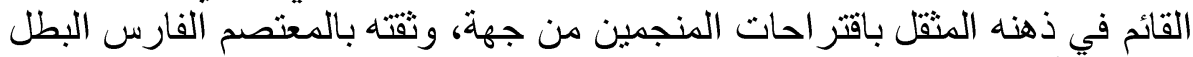

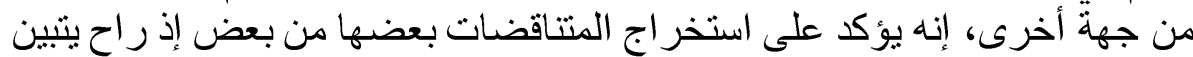

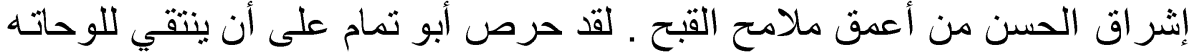

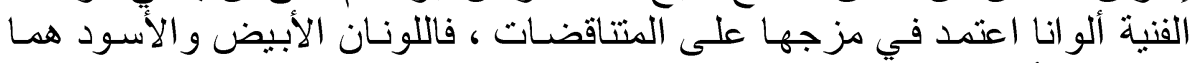

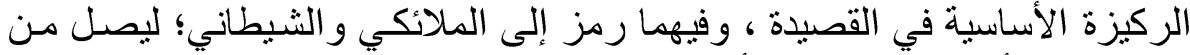

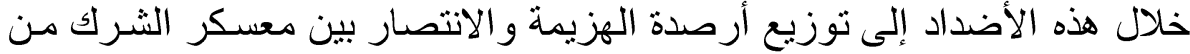

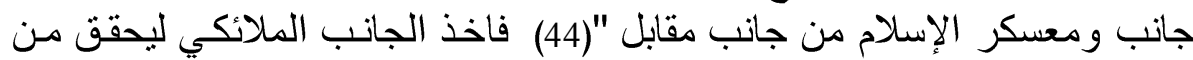

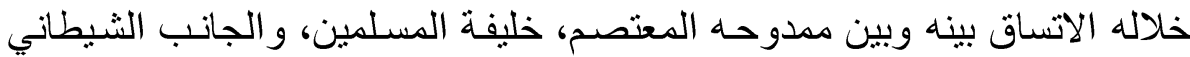

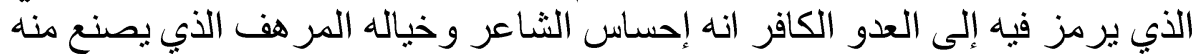

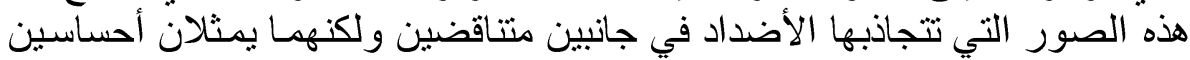

(45)." متغايرين

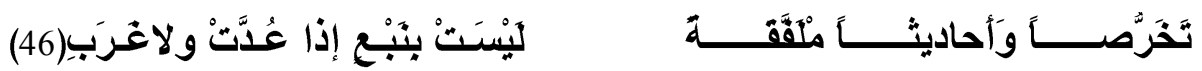

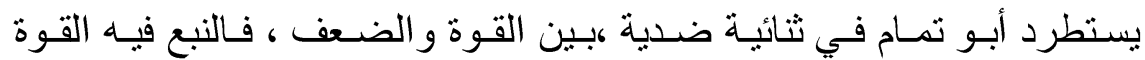

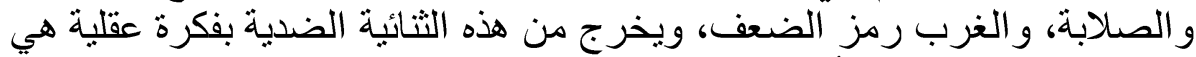

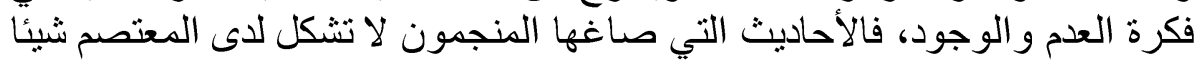

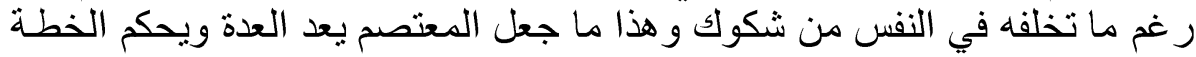


نوافر الأضداد فى شعر أبى تمام قصيدة فتح عمورية أنموذجا

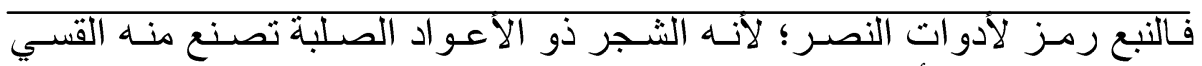

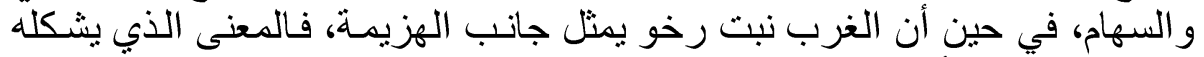

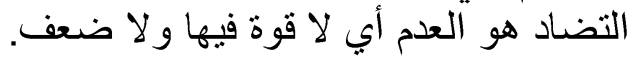

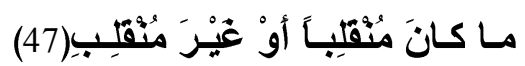

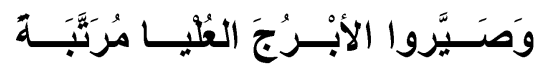

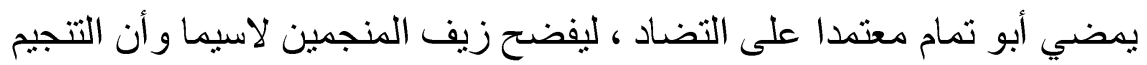

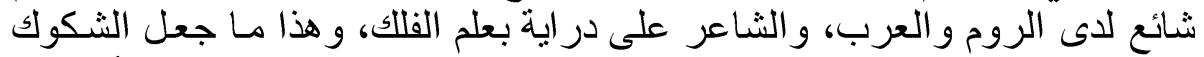

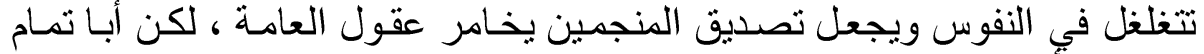

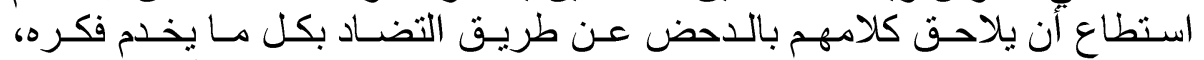

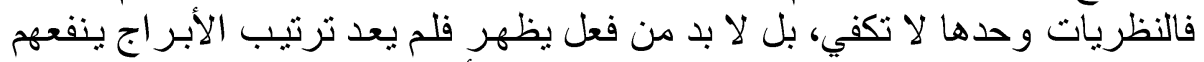

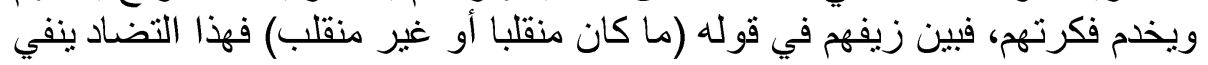

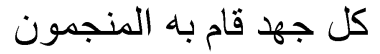

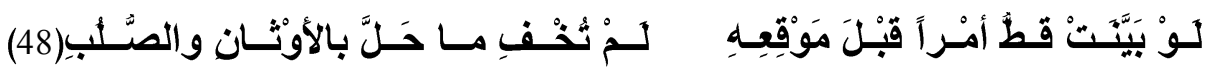

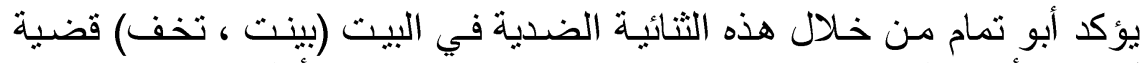

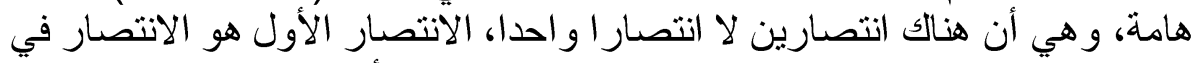

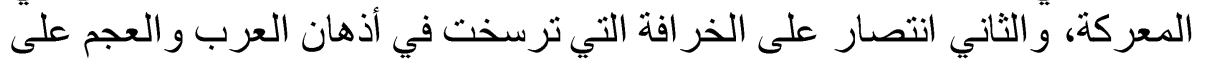

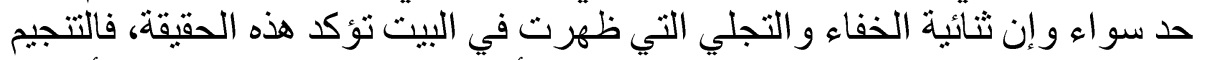

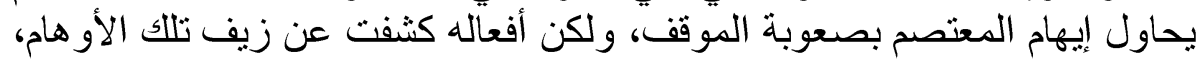

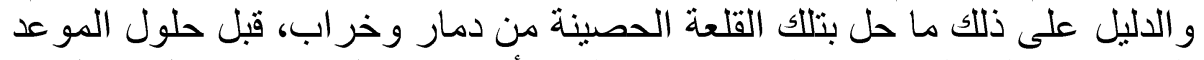

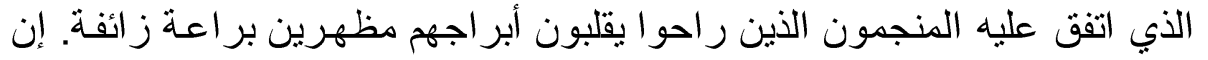

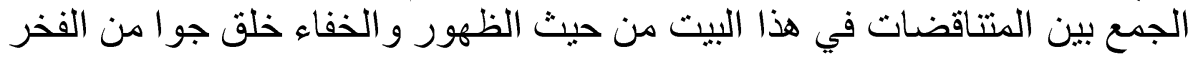
الذي ينعش وجدان الثاعر.

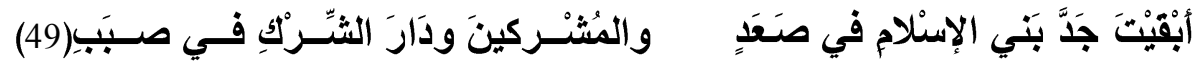

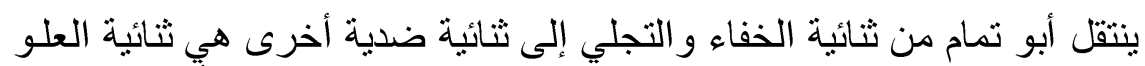

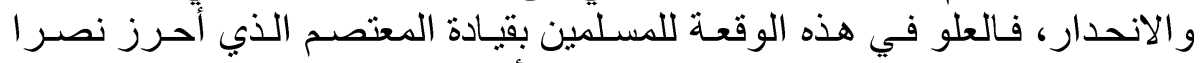

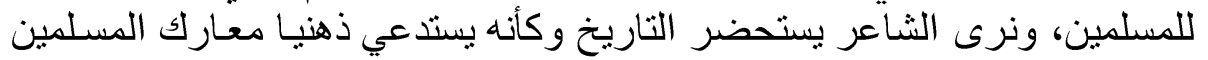

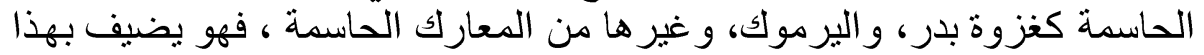

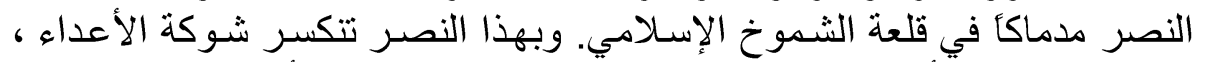

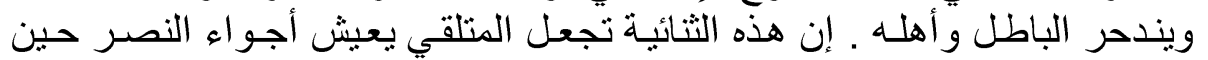

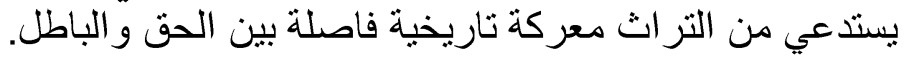




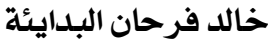

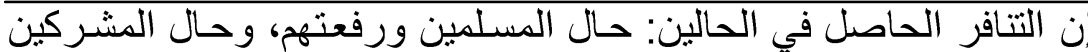

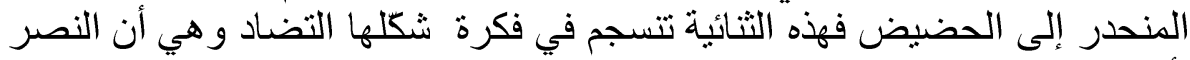
يأتي من رحم الهزيمة.

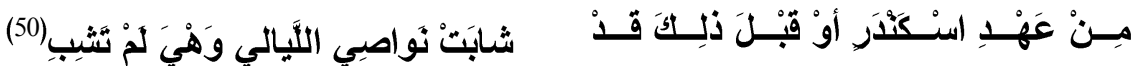

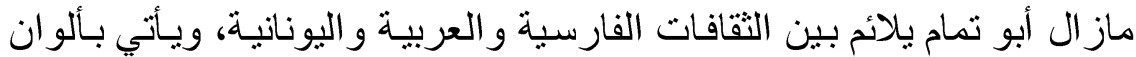

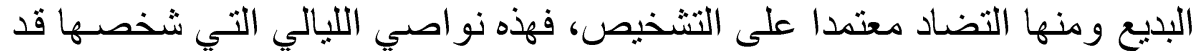

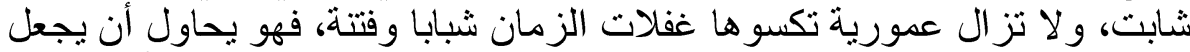

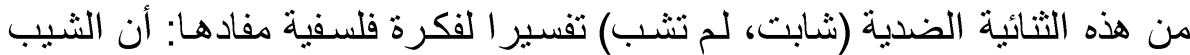

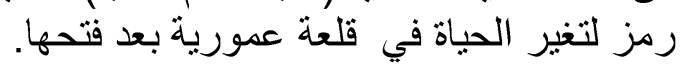

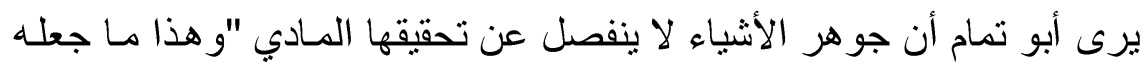
يجمع الأشياء المتنافرة و العناصر المتباعدة في علاقات فريدة تذيب التنافر و التباعد،

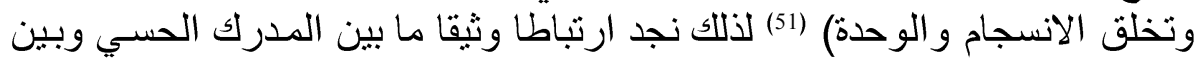

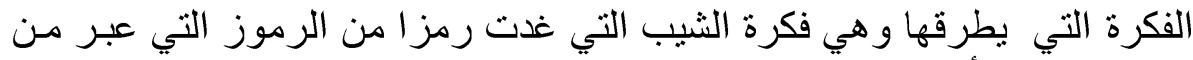

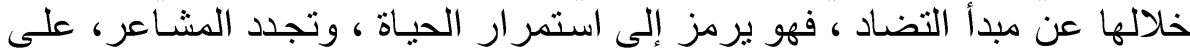

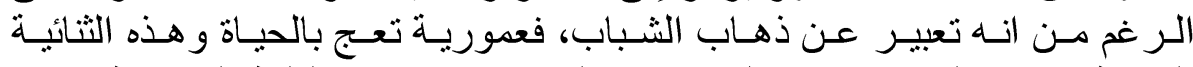

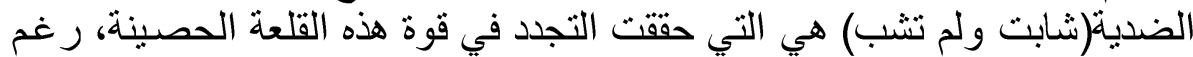

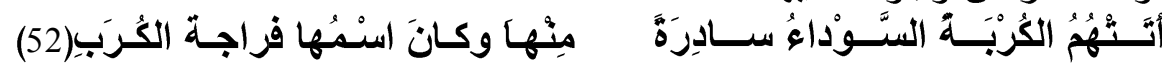

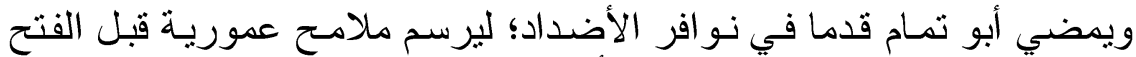

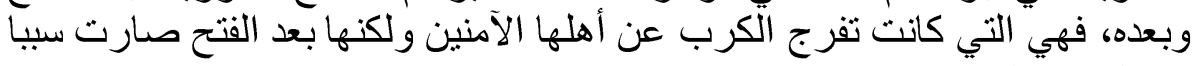
في الكرب الذي بعيشونه.

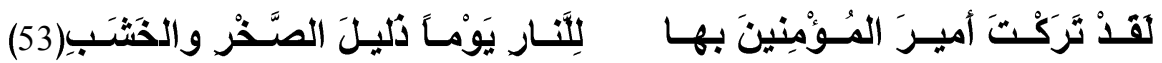

إن الصخر و الخشب ثنائية ضدية تمثل الصلابة و اللين، وتشكل معنَّى يظهر قوة

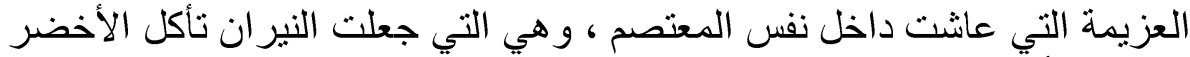

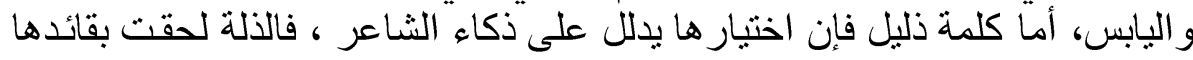

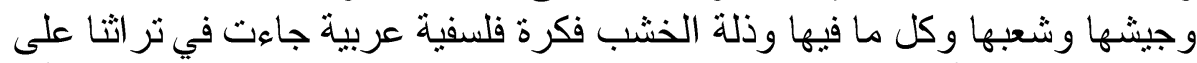

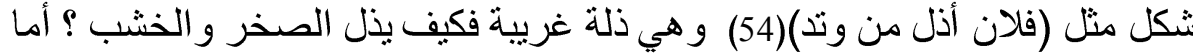

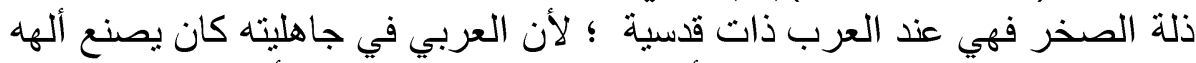
من الصخر ، فالله سبحانه وتعالى أشار إلى ذلك بقوله تعالَّ: (يأيها الذين امنوا اقوا 
نوافر الأضداد فى شعر أبى تمام قصيدة فتح عمورية أنموذجا

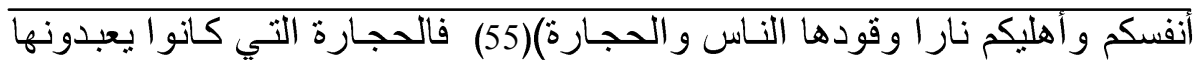

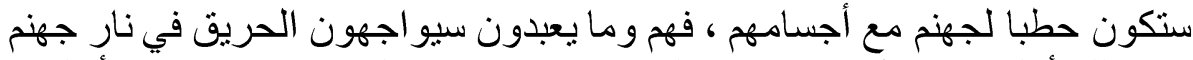

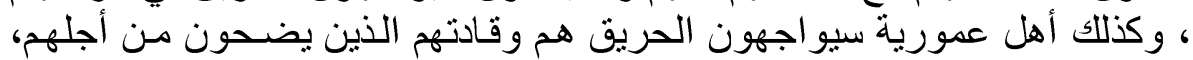

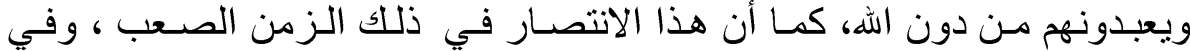
مو ازين القوى التنكافئة سيأتي على كل شيء في تلأل القلعة الحصبينة

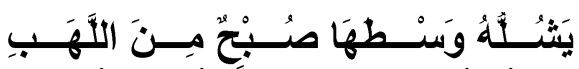

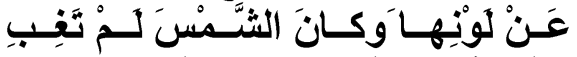

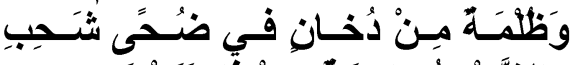

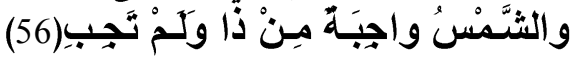

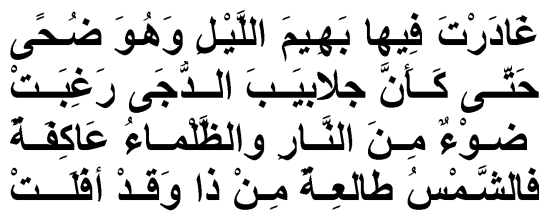

إن المتلقي لهذه الأبيات وما فيها من صور متتاقضة متعارضة رضدا رسمها أبو تمام

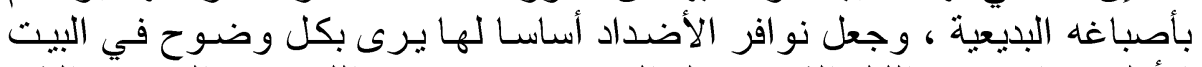

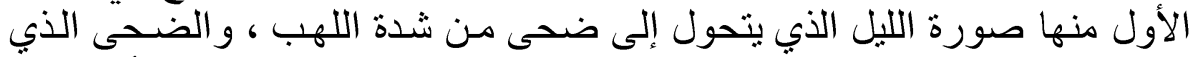

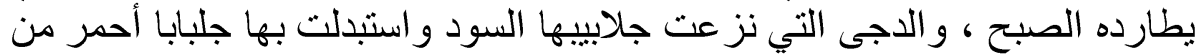

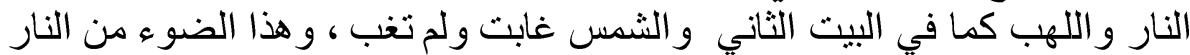

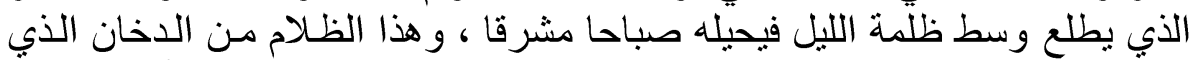

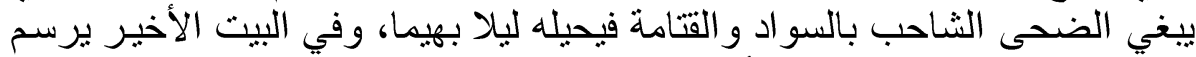

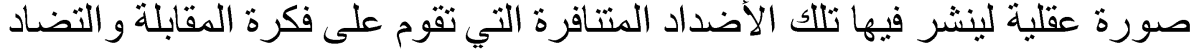

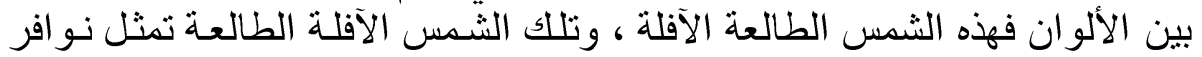

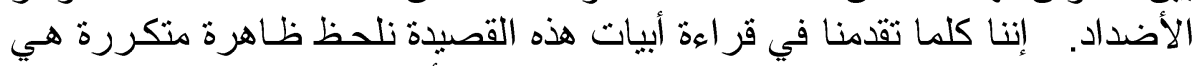

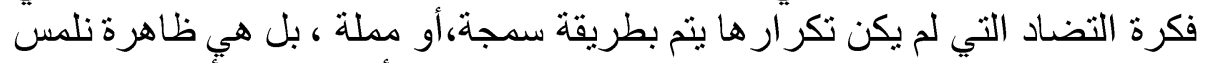

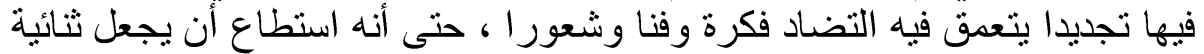

التضاد مبدأ بنتظم فيه إبداعه وفلسفتها في الحباة "(57)

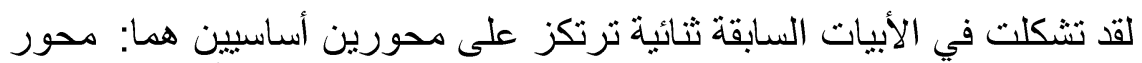

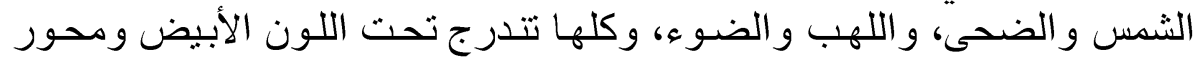

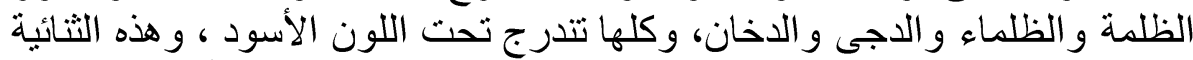

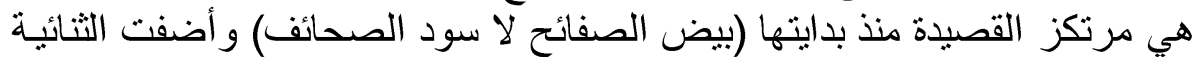

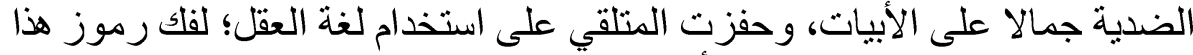

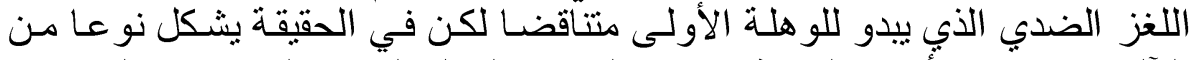

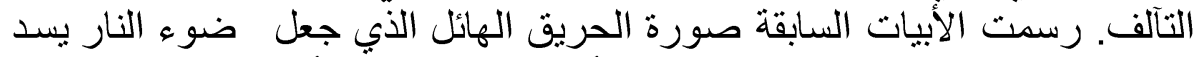

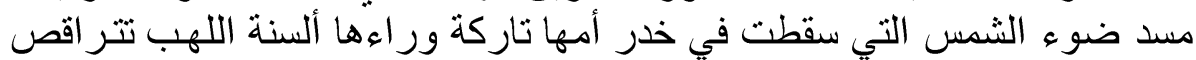

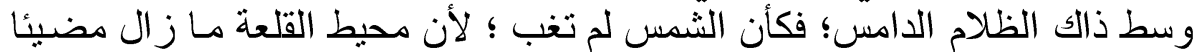
رغم غياب الثمس، إنها حقا لوحة الليل والنهار التي رسمها الثاعر منذ بدا الليل 
خالد فرحان البدايئة

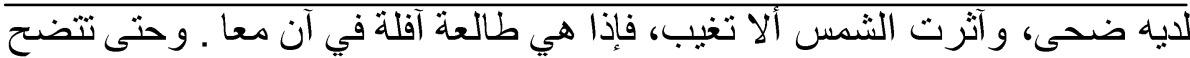

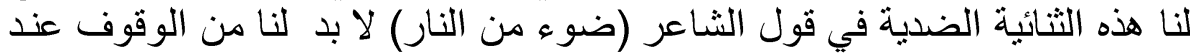
بيت النابغة الذي يصف فئه يوما حربيا:

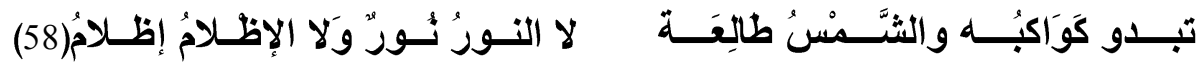

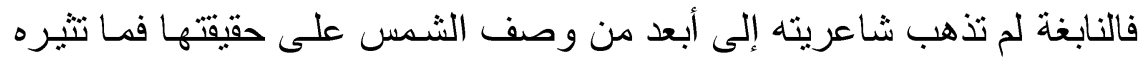

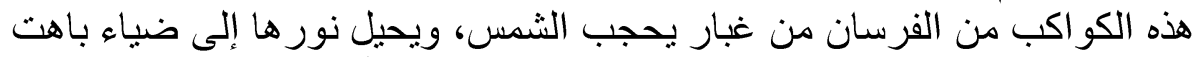

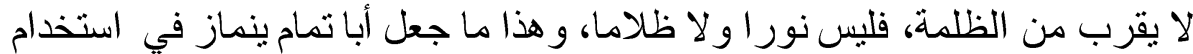

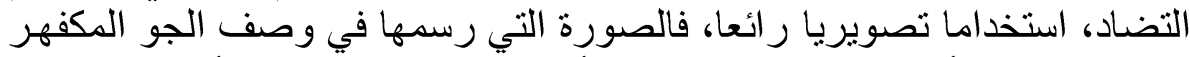

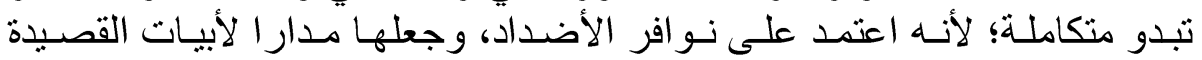

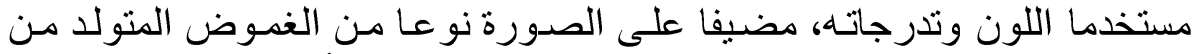

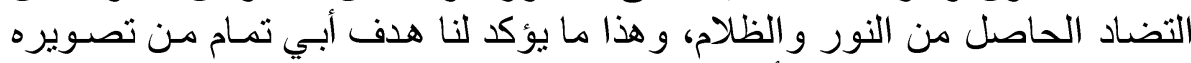

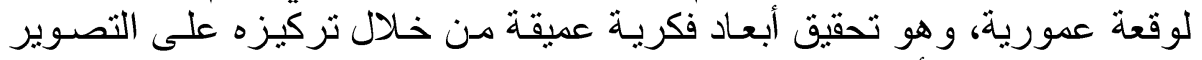

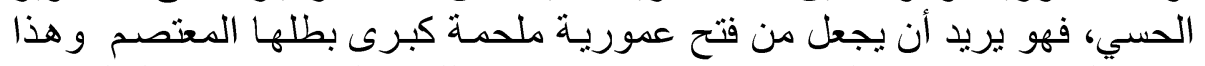

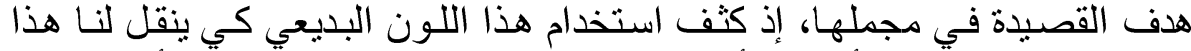

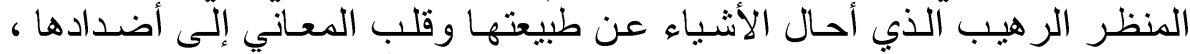
فتولدت في نفسه صورة منعكسة عن تللك الصورة التي أر ادها في حريق عمورية.

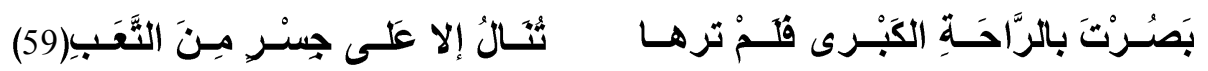

استطاع أبو تمام في هذا البيت أن يجعل الصورة الحسية تثي بالفكرة التي

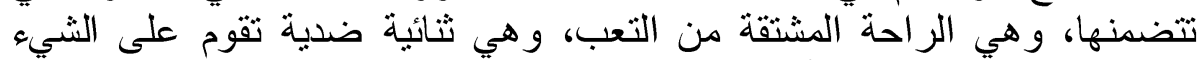

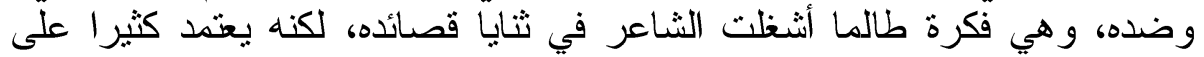

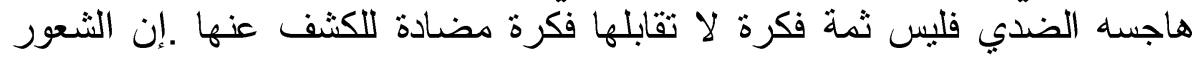

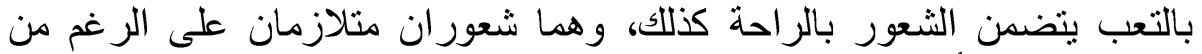

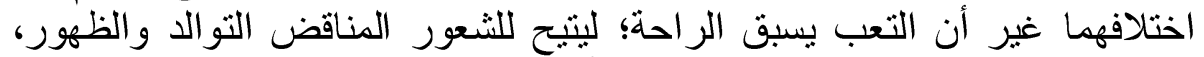

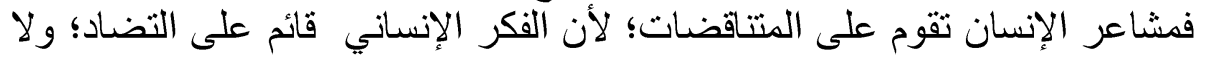

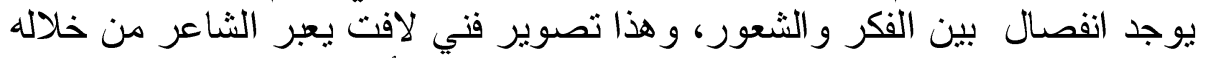

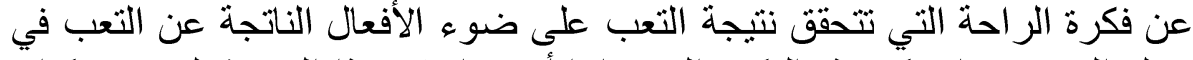

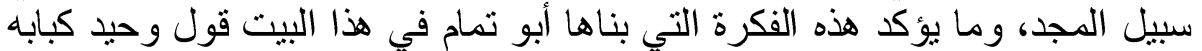

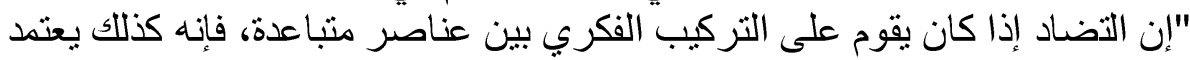

على أساس شعوري يؤلف بين هذه العناصر في لحظة انسجام كوني".(60) وحتى تتضح الصورة نتوقف عند بيتين في مدح عمرو بن طوق التغلبي يؤكد 
فيهما فكرة ثنائية التعب والر احة، يقول:

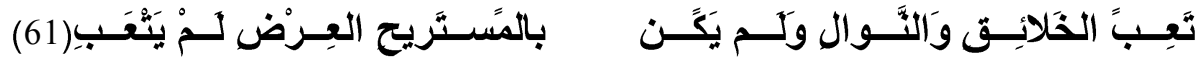

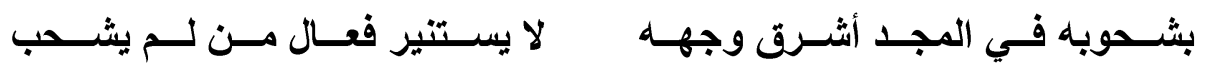
يؤكد أبو تمام فكرة الراحة التي تتحقق نتيجة التعب عن طريق نو التون التر الأضداد

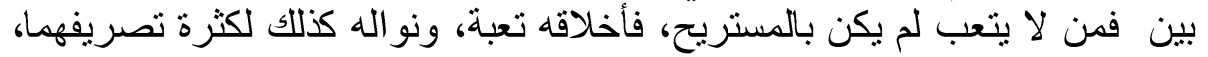

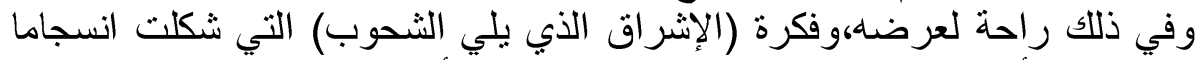

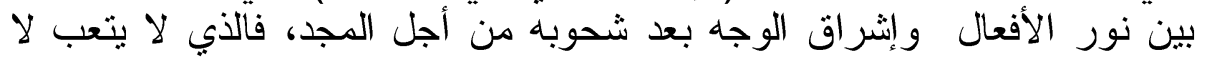

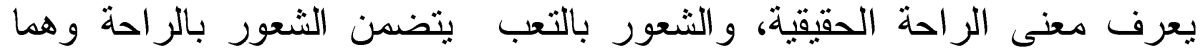
شعور ان منتلازمان رغ رغم اختلافهما.

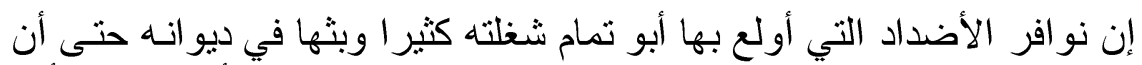

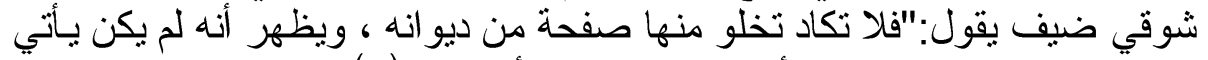

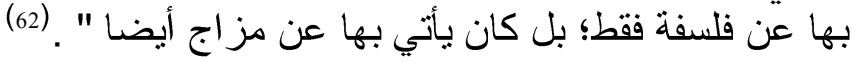

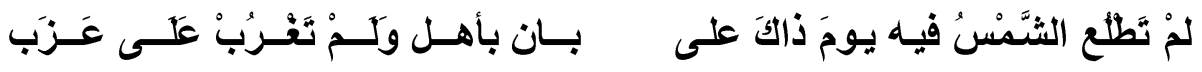

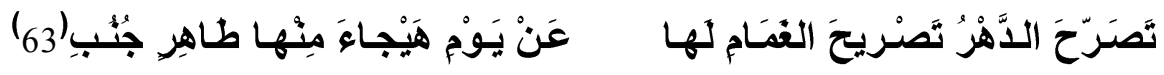

في البيت صورة ذات صياغة تركيبية تقوي التضاد بين كلمتي (طاهر وجنب)

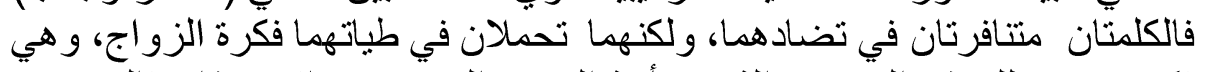

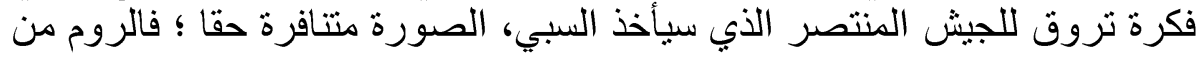

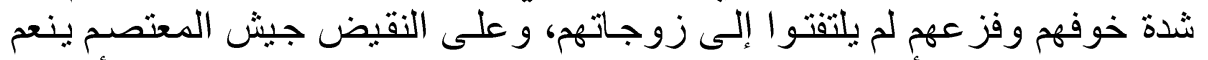

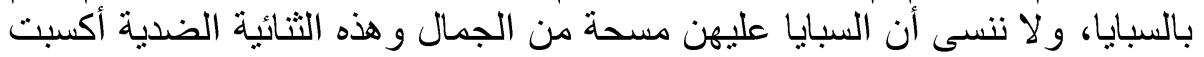

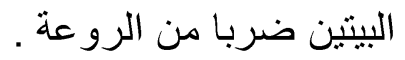

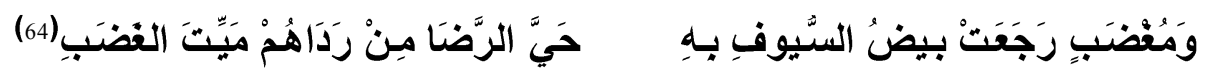

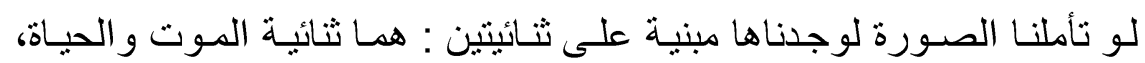

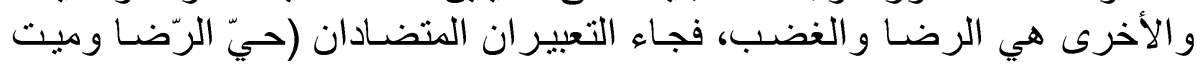

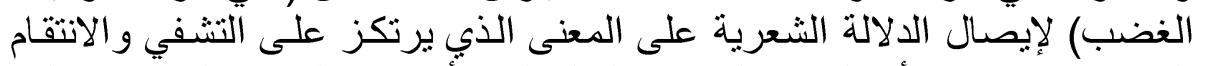

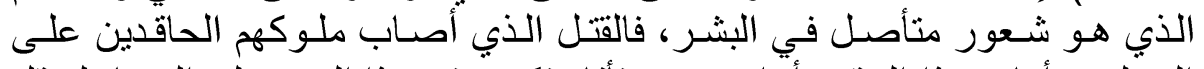

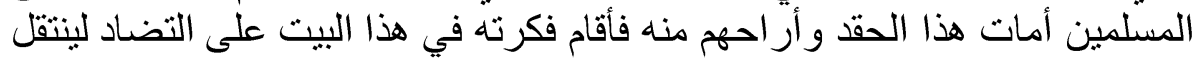

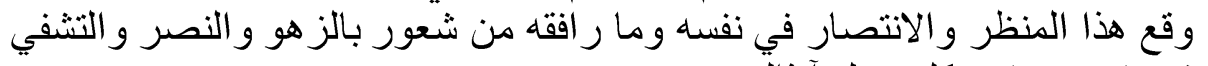
في نفسه، ونفس كل مسلم آنذاك. 


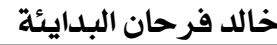

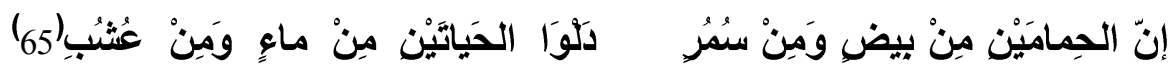

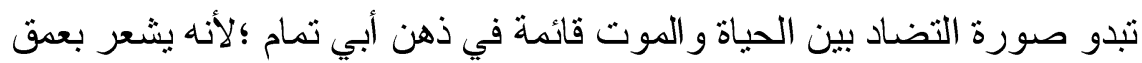

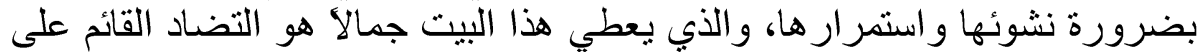

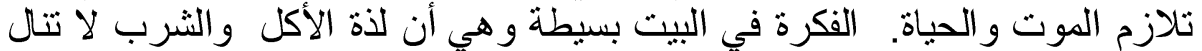

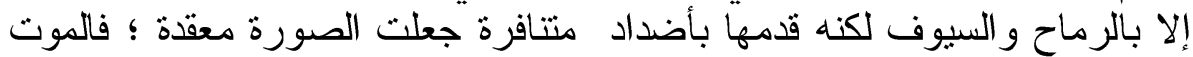

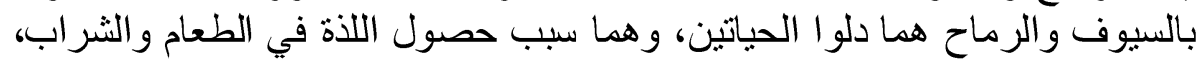

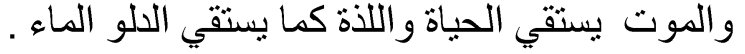

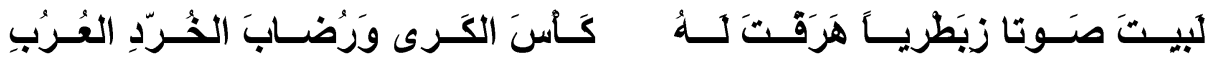

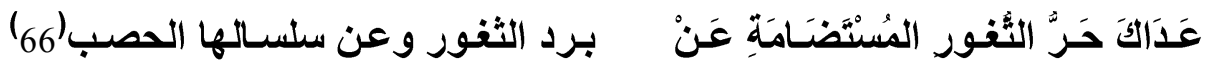

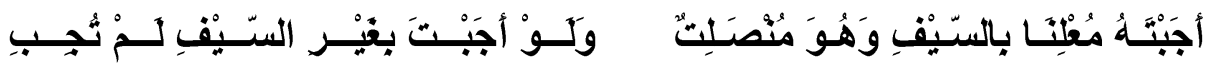

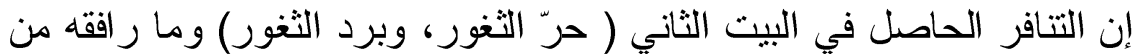

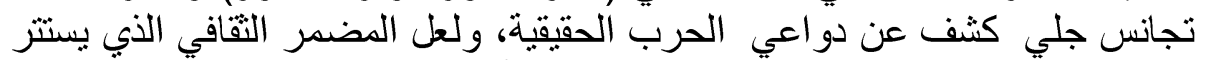

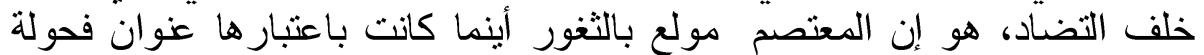

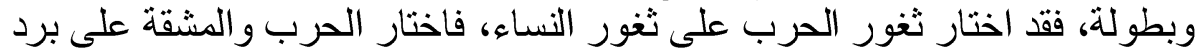

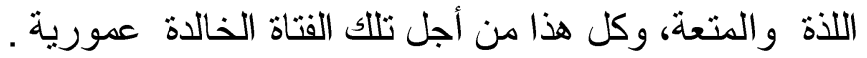

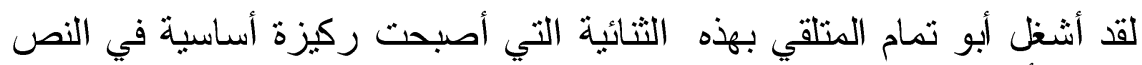

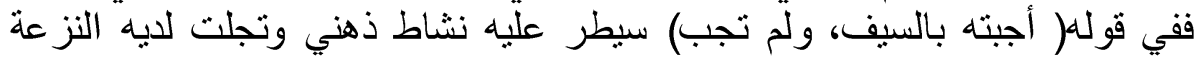

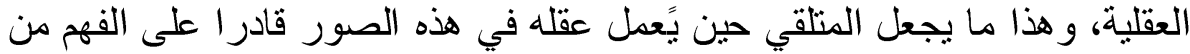

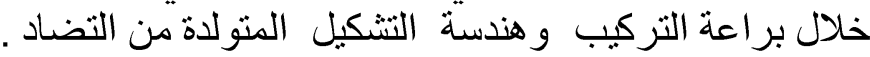

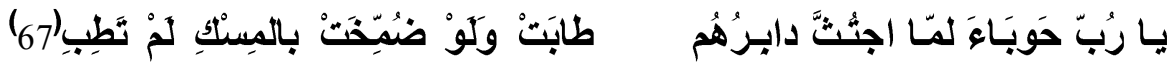

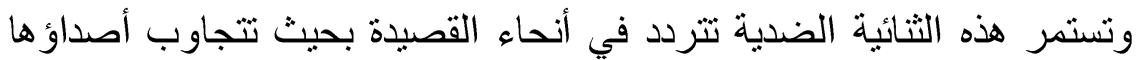

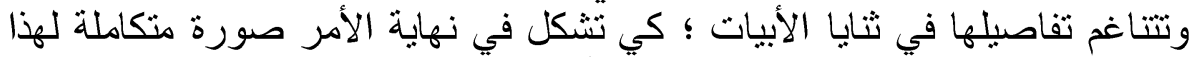

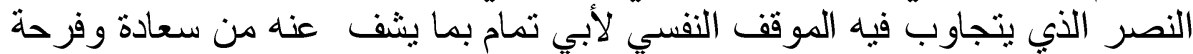

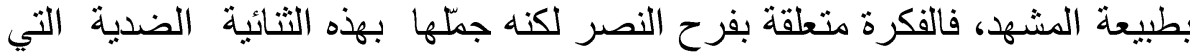

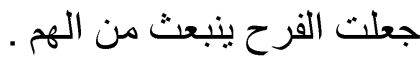

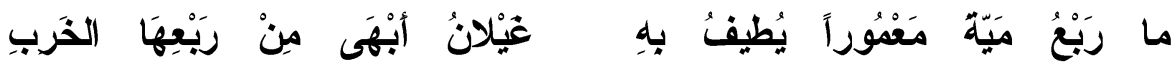




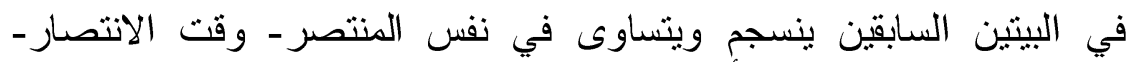

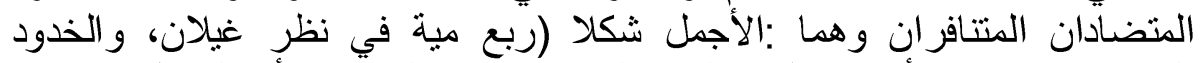

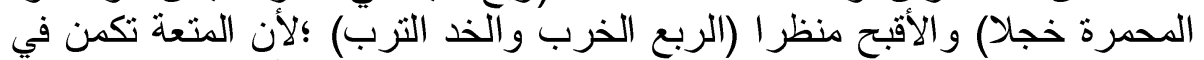

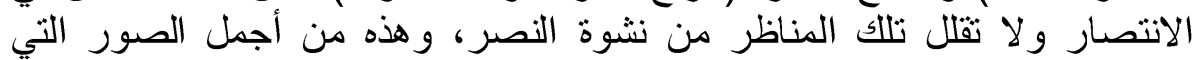

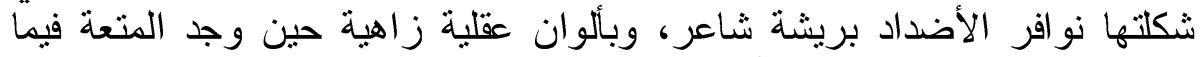

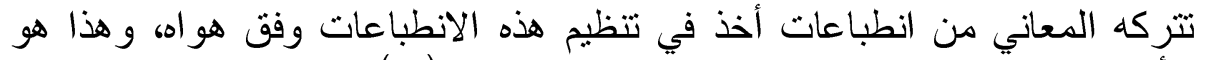
الأساس العميق لذلك العمل الإنساني ألذب نسميه فنا) (69.

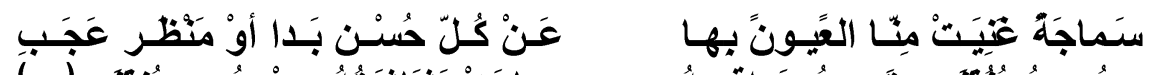

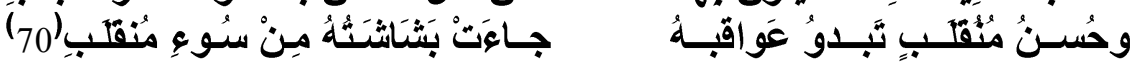

إن لذة نصر المؤمنين في عمورية تولدت من كآبة هزيمة المشركين، و النصر

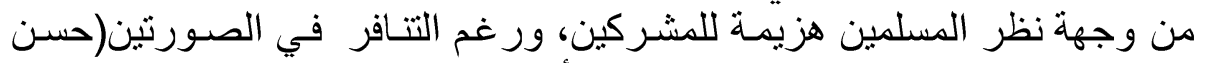

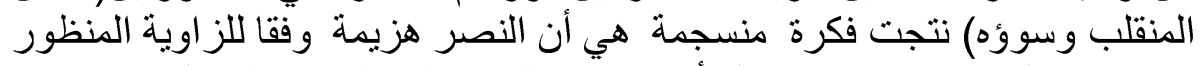

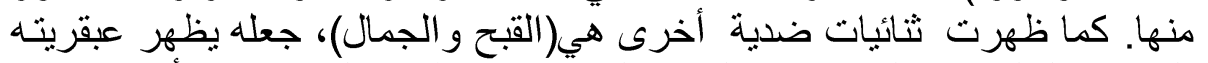

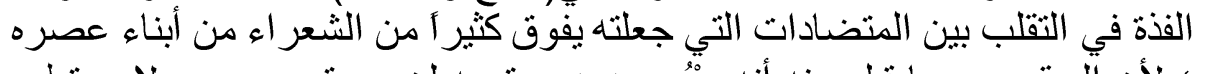

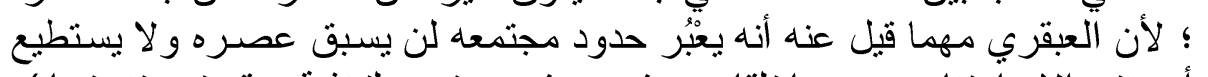

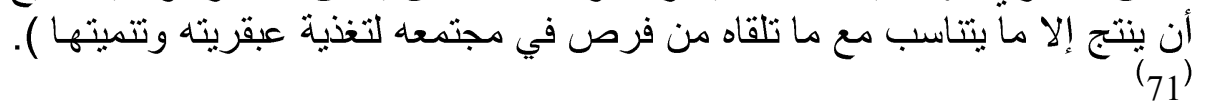

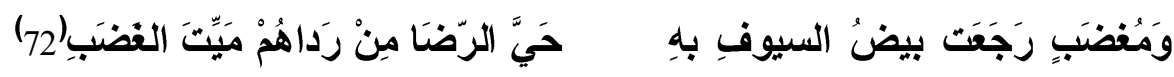

إن نظرة عجلى للبيت تجعل الإنسان برى الثنائيات الضدية بين الموت والحياة،

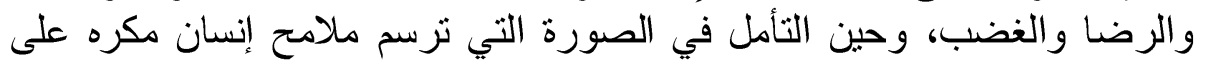

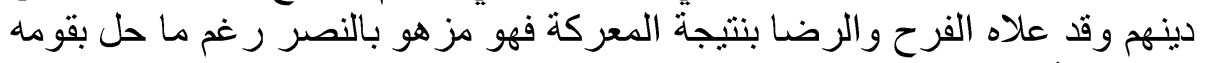

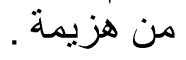

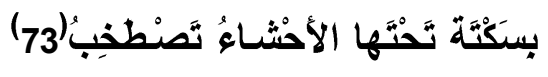

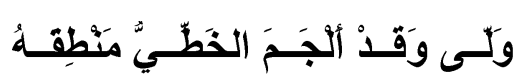

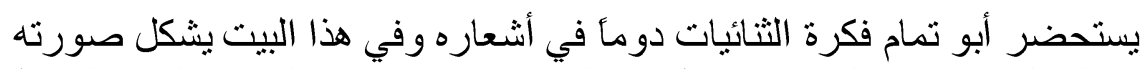

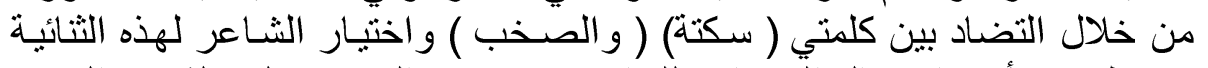

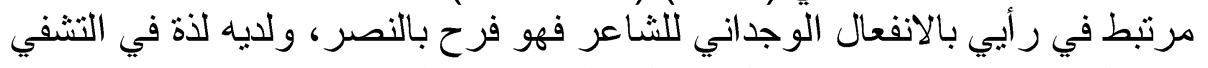

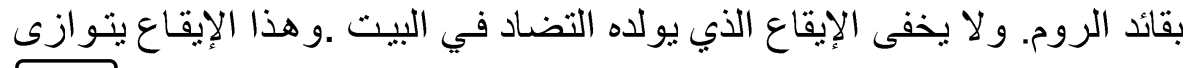


خالد فرحان البدايئة

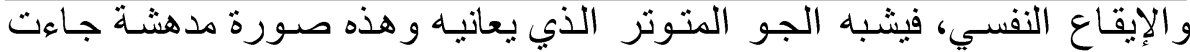

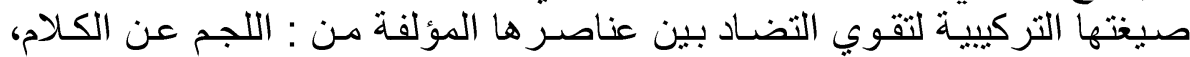
و السكوت، و الصخب، وثرسم بالتالي صورة قائد الروم المنهزين التهن.

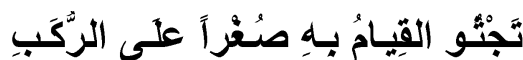

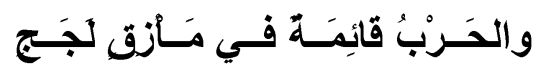

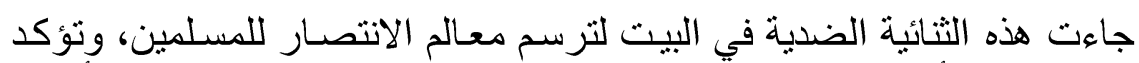

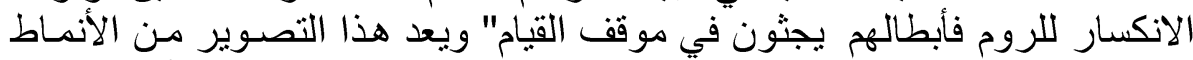

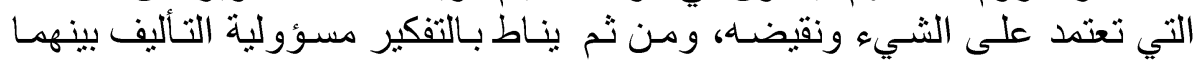

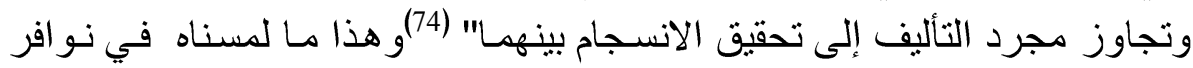

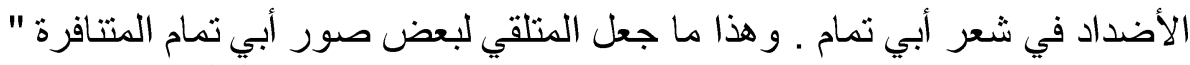

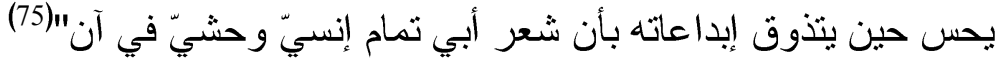

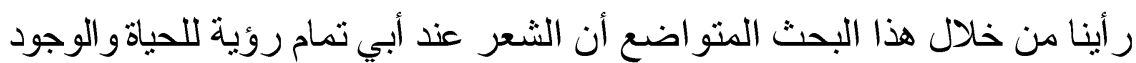

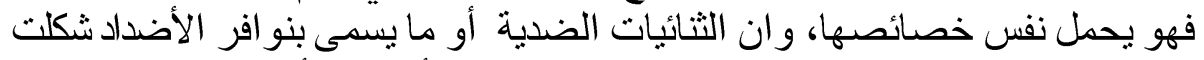
تجليا من تجليات الثاعر العقلية فجاءت معبرة عن أفكاره و أحاسيسها.

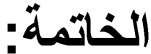

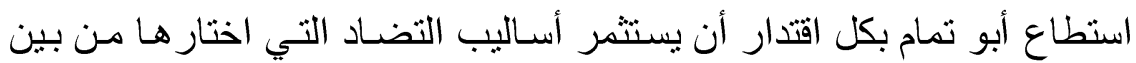

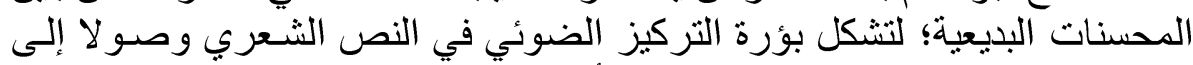

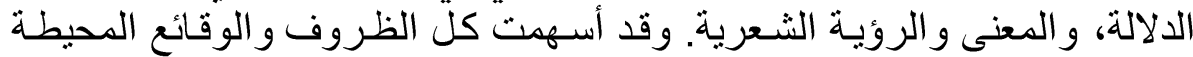

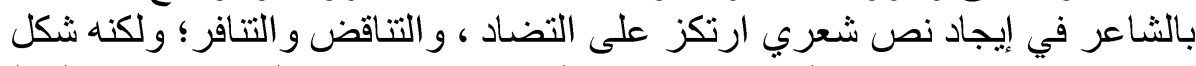

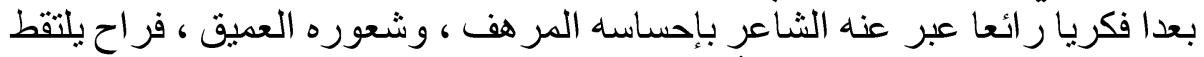

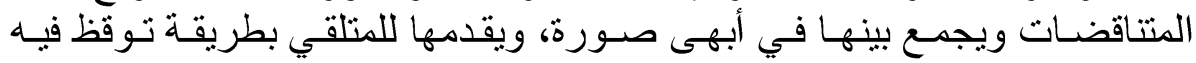

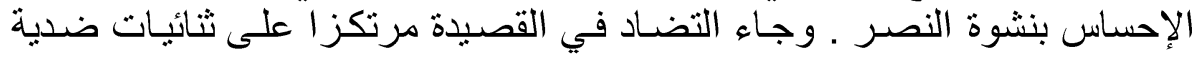

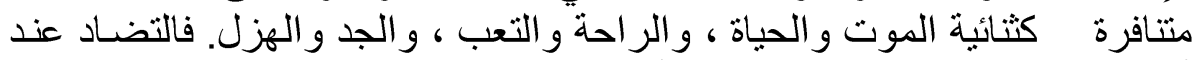

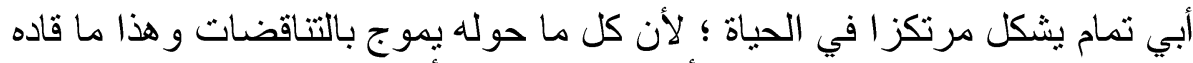

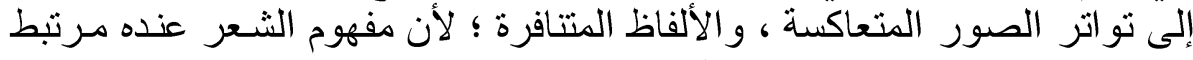

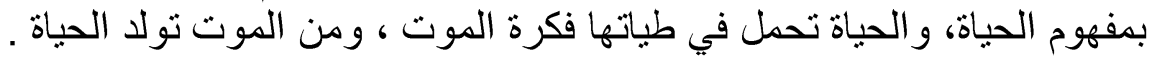

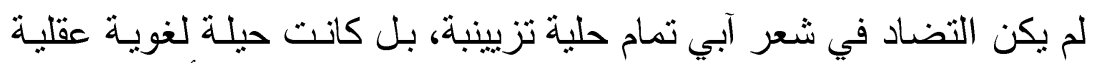

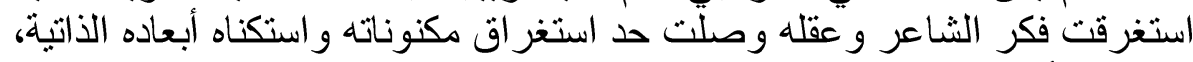

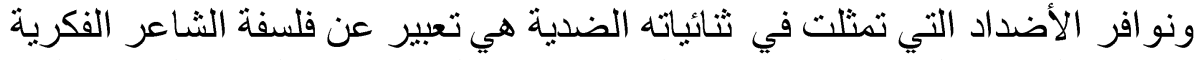

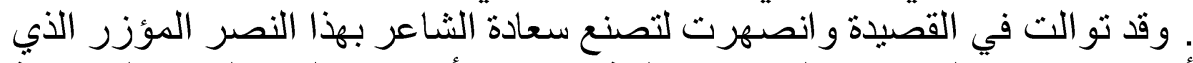

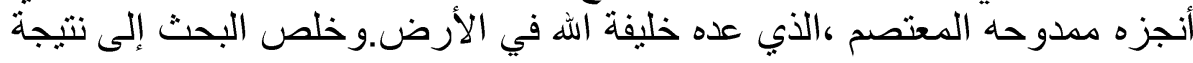


نوافر الأضداد فى شعر أبى تمام قصيدة فتح عمورية أنموذجا

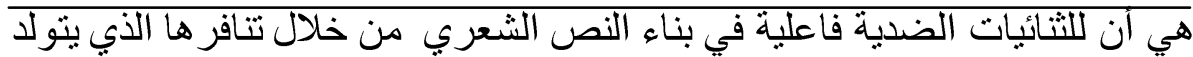

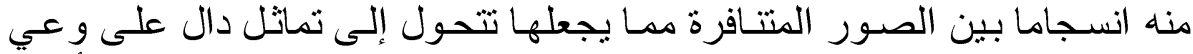

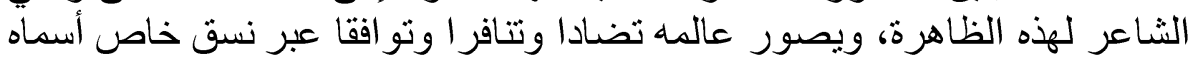

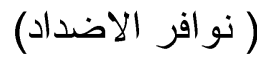

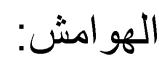

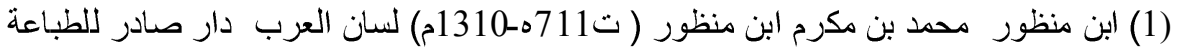

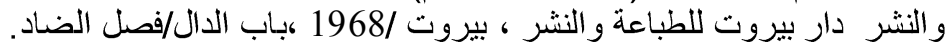

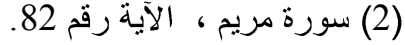




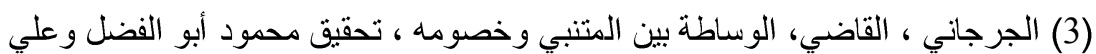

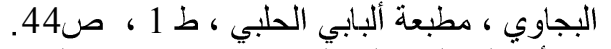

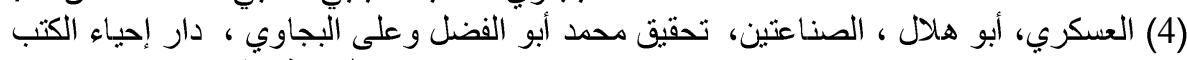

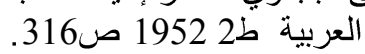

(5) السمرة ، محمود ، النقد الأدبي و الإبداع في الثعر ، المؤسسة العربية للار اسات و النشر ، ط1،

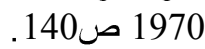

(6) العلوي(يحبى بن حمزة ت745ه )، الطر از التتضمن لأسرار البلاغة وعلوم حقائق الإعجاز

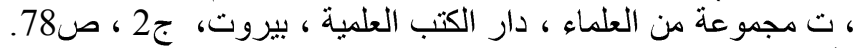

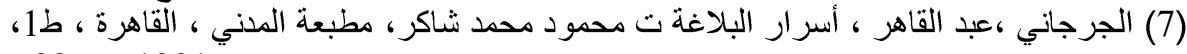

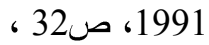

(8) لبابيدي ،سوسن ،ظاهرة التضاد في شعر أبي تمام رسالة ماجستير ، جامعة حلب ، 1995 ،

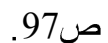

(9) أبو ديب كمال في الثعرية مؤسسة الأبحاث العربية ، بيروت ، 1987، ص21.

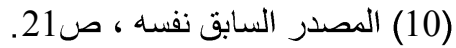

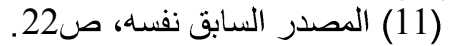

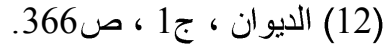

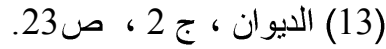

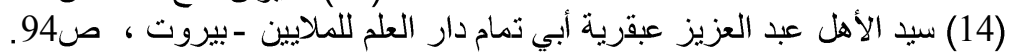

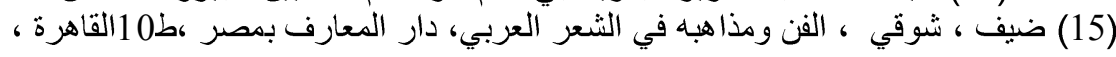

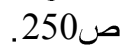

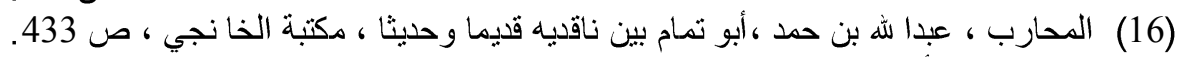

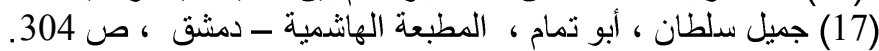

(18 ) نقلا عن : ، عبده بدوي ، أبر ، أبو تمام وقضية التجديد في الثعر ، ص 183.

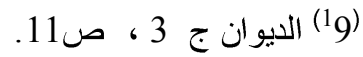

(20) عبد الكريم يافي ، دراسات فنبة في الأدب العربي ، طبعة دمثق ، 1973 ، ص ان جران 74 ـ 75.

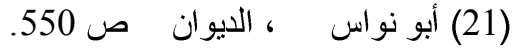

$$
\text { (22) عبد الكريم يافي ، دراسات فنية في الأدب العربي ، ص76. }
$$

(23) محمد عطا ، الثاعر أبو تمام دراسة فنية نفسية ، الدار الفوقية للطباعة والنشر ، القاهرة ،

(24) حاوي ، إيليا ،أبو تمام فنه ونفسيته من خلال شعره ، دار الثقافة ، بيروت ، ط1 ، 1989 ،

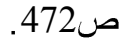

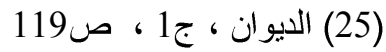

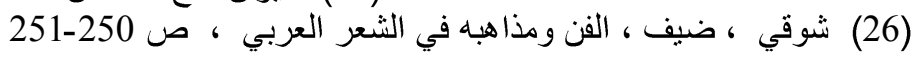

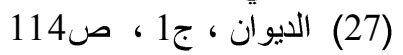

(28) الديوان ، ج3 ، ـ54 ص5 


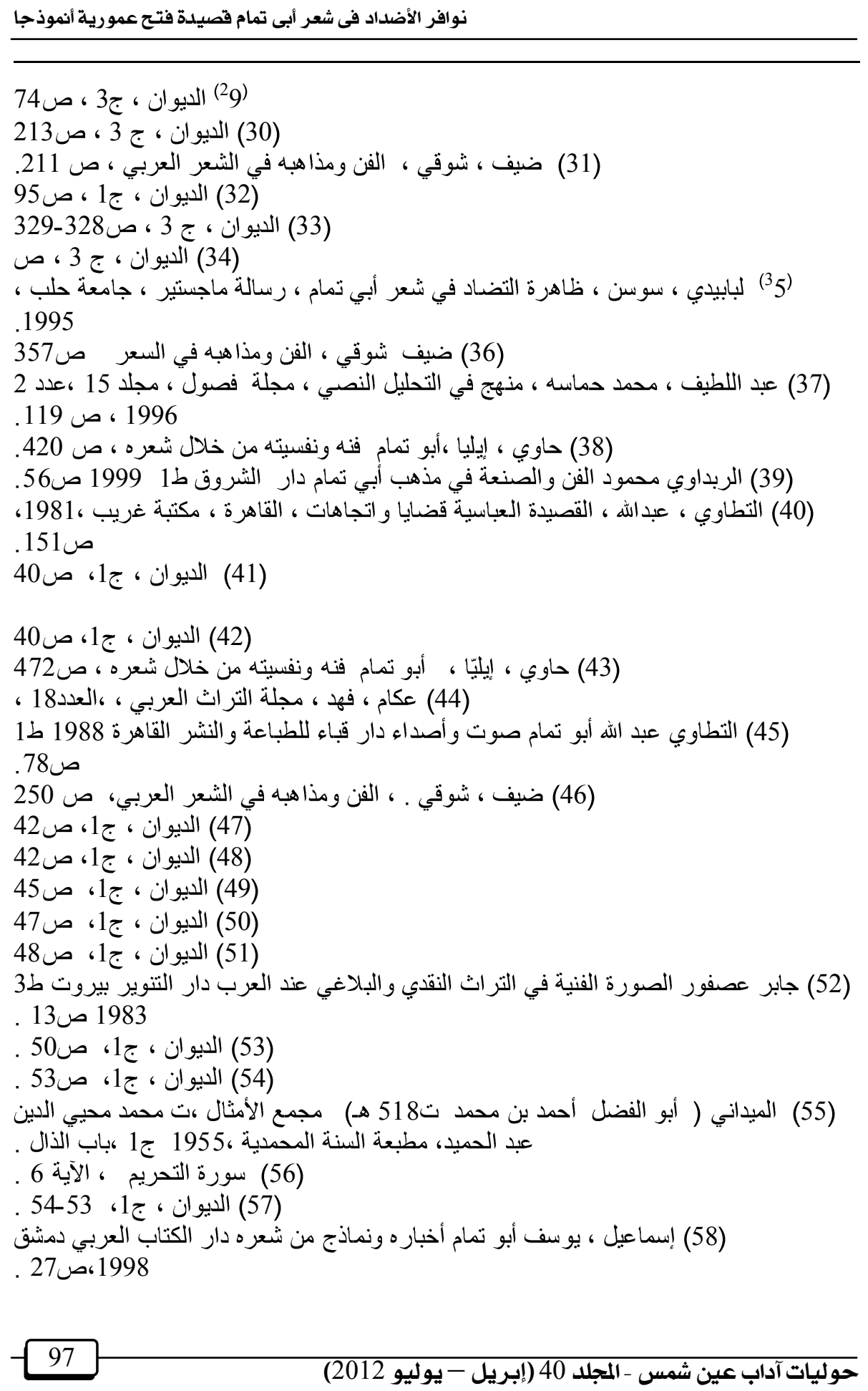


(59) الذبياني ، النابغة ، الديوان ، تحقيق: محمد أبو الفضل إبر اهيم ، دار المعارف ، ط2 ، ص .210

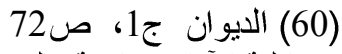

(61) كبابه، وحيد ، الصورة الفنية في شعر الطائيين ، رسالة ماجستير ، كلية الآداب جامعة حلب صل (

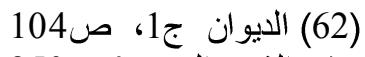

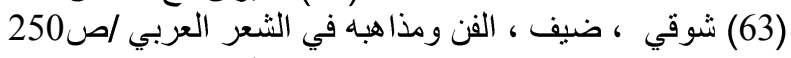

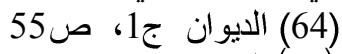

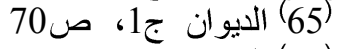

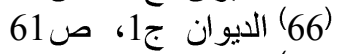

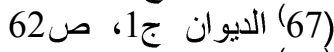

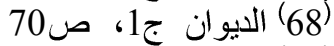

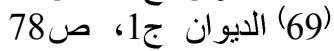

(70) إسماعيل ، عز الدين ، التفسير النفسي للأدب ، دار العودة ، بيروت ط4 ، 19981 ، ص الصان

43

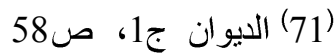

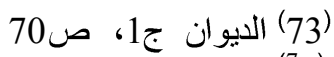

(72) سويف ، مصطفى ، العبقرية في الفن ، ص 101

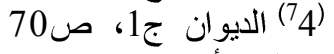

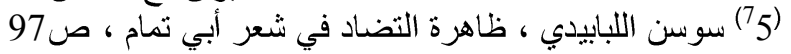

(76) المصري بسرى ،يحيى ،بنية القصيدة في شعر أبي تمام ، الكيئة المصرية العامة للكتاب ، 1997،

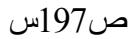

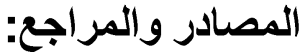

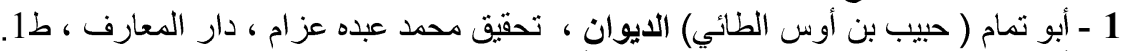

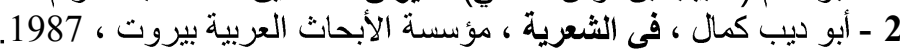

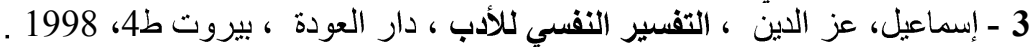

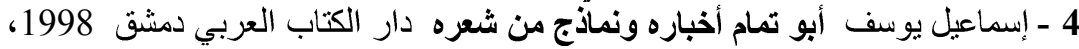

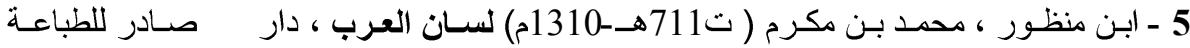

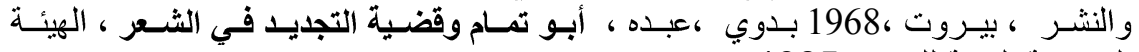

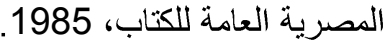

6 - التطــاوي ، عبداله ، القصـيدة العباسـية قضسيا واتجاهـات ، القـاهرة ،مكتبـة غريـبـ

7 - جابر عصفور ، الصورة الفنية في التراث النقدي والبلاغي عند العرب دار التتوير ،بيروت

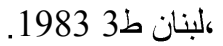

8 - الجرجاني ، عبد التقاهر ، الوسـاطة بين المتنبي وخصومه تحقيق محمود أبو الفضل وعلي

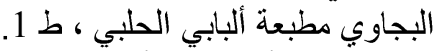
9 -جميل سلطان / أبو تمام ، أبو تمام - جميل سلطان ـ المطبعة الهاشمية ـ دمثق. 


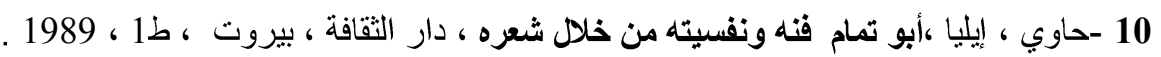

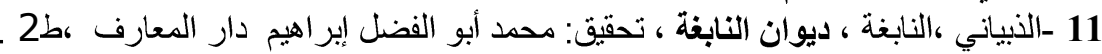

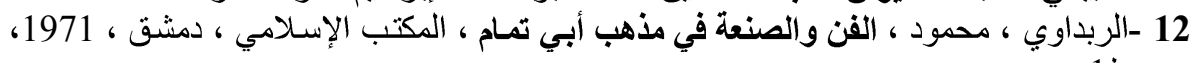

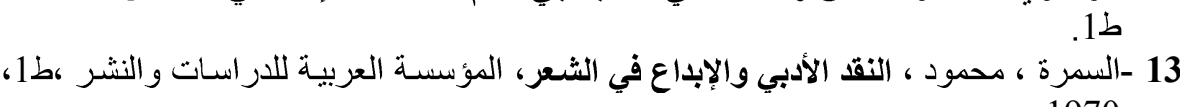

14 -سوسن لبابيدي ، ظاهرة التضاد في شعر ابي تمام ، رسالة ماجستير جامعة حلب ، 1970 ، 1995.

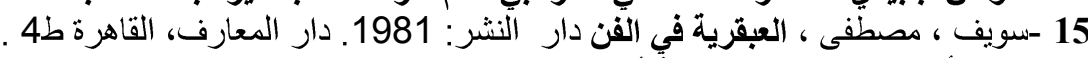

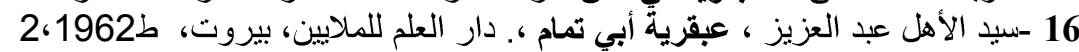

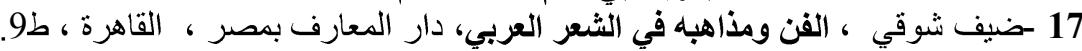

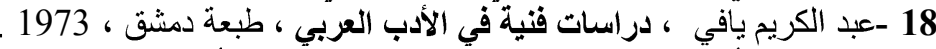

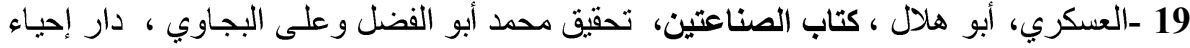

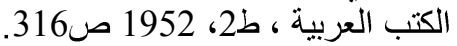

20 -العلوي(يحبى بن حمزة ت ت745ه )، الطراز المتضمن لأسرار البلاغة وعلوم حقائق الإعجاز

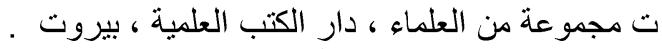

21 -كبابه وحيد ، الصورة الفنية في شعر الطائيين ، رسـالة ماجستير 1984 كليـة الآداب جامعة

حلب

22 -المحارب ، عبدا لله بن حمد ،أبو تمام بين ناقديه قديما وحديثا ، مكتبة الخانجي .

23 ـمحمد عطا ، الثاعر أبو تمام دراسة فنية نفسية ، الدار الفوقية للطباعة و النشر ، القاهرة .

24 - المصري يسرى ،يحيى كبنية القصيدة في شعر أبي تمام ، الهيئة المصرية العامة للكتاب ،

1- - عبد اللظيف ، محمد حماسه ،منهج في التحليل النصي للقصيدة ، مجلة فصول ، مجلد 15

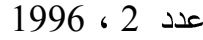

2- عكام ، فهد ، بنية الصورة في شعر أبي تمام، مجلة التراث العربي، دمثق: اتحاد الكتاب

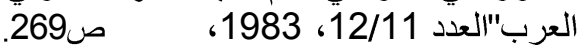

